\title{
WestVirginiaUniversity
}

THE RESEARCH REPOSITORY @ WVU

Graduate Theses, Dissertations, and Problem Reports

2012

\section{Politics of Memory with Regard to the Ukrainian Minority in Poland after 1989}

Joanna Klimczak

West Virginia University

Follow this and additional works at: https://researchrepository.wvu.edu/etd

\section{Recommended Citation}

Klimczak, Joanna, "Politics of Memory with Regard to the Ukrainian Minority in Poland after 1989" (2012). Graduate Theses, Dissertations, and Problem Reports. 4877.

https://researchrepository.wvu.edu/etd/4877

This Thesis is protected by copyright and/or related rights. It has been brought to you by the The Research Repository @ WVU with permission from the rights-holder(s). You are free to use this Thesis in any way that is permitted by the copyright and related rights legislation that applies to your use. For other uses you must obtain permission from the rights-holder(s) directly, unless additional rights are indicated by a Creative Commons license in the record and/ or on the work itself. This Thesis has been accepted for inclusion in WVU Graduate Theses, Dissertations, and Problem Reports collection by an authorized administrator of The Research Repository @ WVU. For more information, please contact researchrepository@mail.wvu.edu. 
Politics of Memory with Regard to the Ukrainian Minority in Poland after 1989

\author{
Joanna Klimezak
}

Thesis submitted to the Elberly College of Arts and Sciences at West Virginia University in partial fulfillment of the requirements for the degree of

Master of Art in History

Robert Blobaum, Ph.D., Chair

Joshua Arthurs, Ph.D.

Elizabeth Fones-Wolf, Ph.D.

Department of History

Morgantown, West Virginia

2012

Keywords: Poland; Ukrainian minority; Memory politics; Social integration; Polish-Ukrainian relations

Copyright 2012 Joanna Klimczak 


\section{ABSTRACT \\ Politics of Memory with Regard to the Ukrainian Minority in Poland After \\ 1989 \\ Joanna Klimczak}

The present thesis discusses the nature of majority- minority relations in Poland after 1989. Among other things, democratic and geopolitical changes after 1989 have been associated with protection of minority rights. In order to implement respect for minorities into Polish reality, the state had to guarantee the rights of minorities. One of the key elements in the process of official recognition and integration of minorities in the Polish state was the emergence of a particular attitude and forms of cultural awareness in relation to the past. The subject of this thesis is to analyze the politics of memory and the historical awareness with regard to the Ukrainian minority, focusing particularly on the reflection of the painful memories of events of World War Two and the post-war years. I look beyond the wellknown prejudices and examine the ways used by authorities after 1989 to create and maintain a particular model of memory politics. This study examines the process of integration of Ukrainian minority into Polish society from the perspective of memory politics. The integration of a minority's memory into Polish mainstream interpretations became the objective of the Polish government which was and still is pursued. 
I have written the work independently. All works of other scholars, their principled positions, and data from written sources and from elsewhere that have been used in preparing this work have been cited.

Ithe author's signature 


\section{Table of Contents}

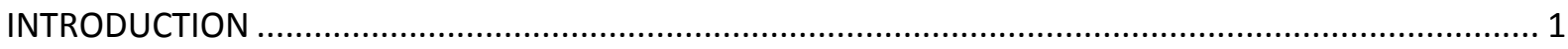

Chapter 1: Changes of 1989 and the Polish Memory...................................................................... 9

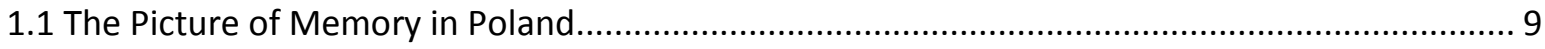

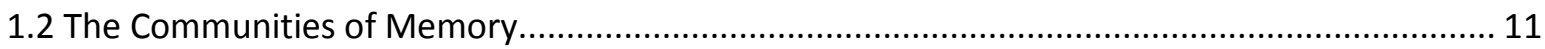

1.3 The Ukrainian community of memory- what determines their memory? Crimes of World War

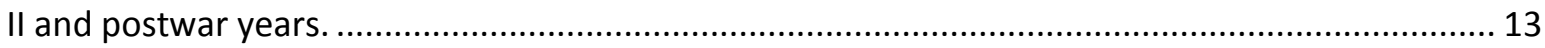

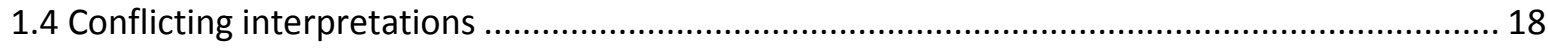

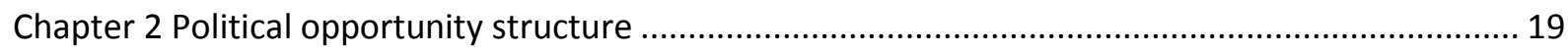

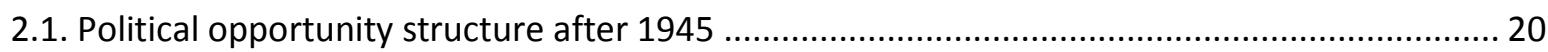

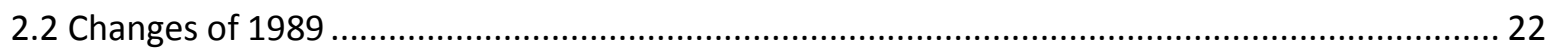

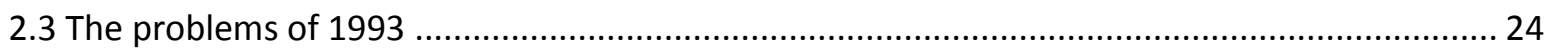

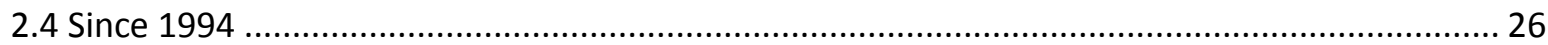

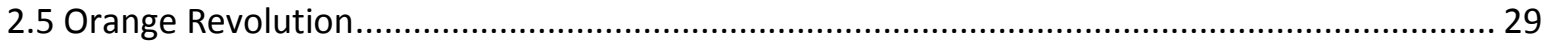

Chapter 3 Politics of memory toward the Ukrainian Minority.......................................................... 32

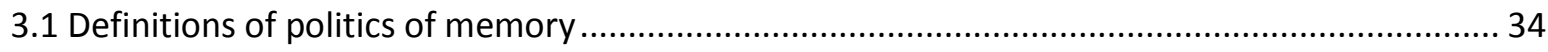

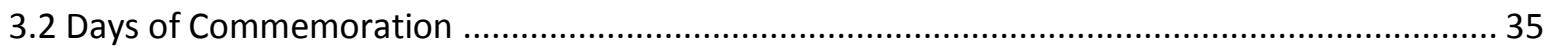

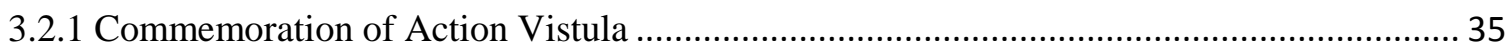

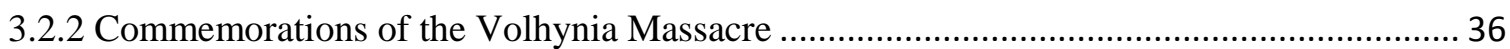

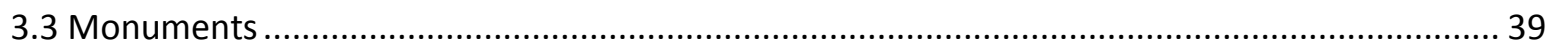

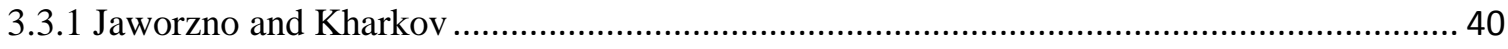

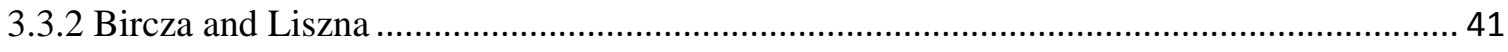

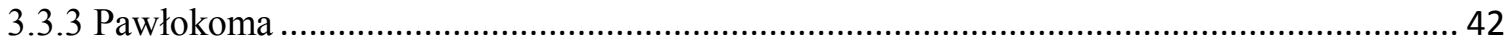

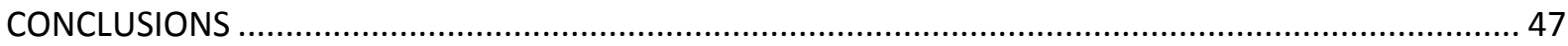

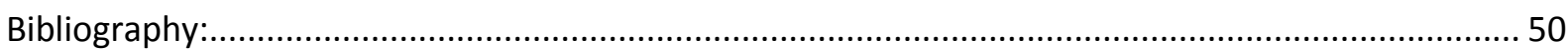




\section{INTRODUCTION}

Poland is a country situated in Central Europe. It shares borders with the Czech Republic and Slovakia to the south, Germany in the west, Ukraine, Belarus and Lithuania to the east and in the north with the Russian exclave, Kaliningrad Oblast. Poland is inhabited by over 38 million people. According to the Polish census of 2002, 471,474 non- Polish people live in Poland. ${ }^{1}$ Polish society became relatively homogeneous as a result of the turbulent time of World War II, altered borders and the post- war deportations of minorities. ${ }^{2}$ From the end of Second World War to 1989 Poland functioned under Soviet influence as the Polish People's Republic. The Revolution of 1989 led to the first free and democratic parliamentary elections since the interwar period and put an end to communist rule in Poland. As a country in transition, Poland with its multilayered historical heritage had to define minorities' place in society and their rights. Democratization after 1989 was accompanied by the establishment of pillars of a state based on the rule of law. For communities which were distinguished by different cultures, religions and national identities it meant the regulation of their rights and freedoms and, finally, an opportunity to express their identity. It was a huge challenge for both the authorities and the society. Not only because it required legal changes with regard to minorities' status but because it demanded change in terms of attitude toward minority groups.

The legal framework in relation to minorities included the Constitution of 1997 which stated in article 35 that all Polish citizens who belong to national and ethnic minorities have the freedom to maintain and develop their own language, customs, tradition and culture. ${ }^{3}$ What is more, to achieve its goal of becoming a member of the European Union (EU) Poland as well as other Central and Eastern countries had to meet certain membership requirements,

\footnotetext{
${ }^{1}$ Central Statistical Office, "Wyniki Narodowego Spisu Powszechnego Ludności i Mieszkań 2002 w zakresie deklarowanej narodowości oraz języka używanego w domu," Central Statistical Office, http://www.stat.gov.pl/gus/8185_PLK_HTML.htm (accessed September 21, 2010).

${ }^{2}$ Between 1944-1946 Soviet authorities ordered forced migrations of almost eighty thousand to one hundred thousand Poles and Ukrainians who inhabited the Polish territories annexed by the Soviet Union. They were settled in formerly German provinces, after 1945 known as Recovered Territories of People' s Republic of Poland. For more extended discussion on ethnic cleansing in East Central Europe see, Jerzy Kochanowski, "Gathering Poles into Poland: Forced Migration From Poland's Former Eastern Territories," in Redrawing Nations : ethnic cleansing in East- Central Europe, 1944- 1948, ed. Philipp Ther and Ana Siljak (Lanham, Maryland: Rowman\& Littlefield Publishers, 2001), 135-154.

${ }^{3}$ Polish Constitution, 2nd April 1997, passed by National Assembly on 2nd of April 1997, adopted by the Nation in the constitutional referendum on $25^{\text {th }}$ of May 1997, signed by the president on $16^{\text {th }}$ of July, 1997.
} 
one of which was respect and protection of minority rights. ${ }^{4}$ As a result, in 2001 Poland ratified the Council of Europe Framework Convention for the Protection of National Minorities. ${ }^{5}$ In 2005 based on article 35 of the Constitution of 1997, Poland adopted the Law on National and Ethnic Minorities and Regional Language. The process of preparation of this law was one of the longest in Poland after $1989 .{ }^{6}$

The adopted legal solutions with regard to protection of minorities seemed to be very good and effective. It gave the impression that Poland had introduced a good basis for minorities to keep and develop their identity as well as to develop itself as an open and tolerant country, reoriented toward Europe. Nevertheless, development of the legal framework for minorities is just one of many elements which leads to society's openness, tolerance and most of all awareness and acceptance of cultural differences. A democratic country should actively undertake actions to develop openness and tolerance which was and still is a difficult issue in Poland with regard to any kind of minorities. First, because in postwar Poland protection of minorities did not have a place in common memory. Secondly, because democratic transition was accompanied by a certain exaltation of national emotions; thirdly, because of a complicated policy of memory and historical narrative with regard to minority groups which to a large degree influenced and shaped the society's attitudes in relation to minorities. I would like to throw more light on the latter issue.

It is necessary to explain why the politics of memory with regard to minorities is of special importance. The integration of minorities and immigrants is the subject of lively debate in contemporary Europe. It takes place both at the EU level as well as at the level of the EU Member States. The goal of such integration is to enable these populations to live in the European community, and to study, work and integrate with the local communities in which they live. One of the elements of such integration and a huge challenge for the EU

\footnotetext{
${ }^{4}$ Part of the Copenhagen criteria which define whether a country is eligible to join the European Union. See Copenhagen European Council, "Presidency Conclusions," Copenhagen European Council, http://www.europarl.europa.eu/enlargement/ec/pdf/cop en.pdf (accessed July1, 2011).

${ }_{5}^{5}$ Sławomir Łodzińśki, The Protection of National Minorities in Poland. Warsaw (Warsaw:Helsinki Foundation for Human Rights, 1999).

${ }^{6}$ A draft of the act was created in 1998 by Jacek Kuron, then President of the Parliamentary Committee on National and Ethnic Minorities. However, it did not receive much of attention from the Members of Parliament for almost 4 years. The act called for introduction of minority language as an auxiliary language in the areas of selected municipalities. The problem turned out to be the criteria for selection of these municipalities. For more extended discussion on disputes concerning the draft law, see Sławomir Łodziński, "Wyrównanie czy uprzywilejowanie. Spory dotyczące projektu ustawy o ochronie mniejszości narodowych (1989-2005)", Kancelaria Sejmu Biuro Studiów I Ekspertyz, no. 232, March, 2005.
} 
is the question of shared European identity, of which memory is a main component. According to Anthony Smith, one of the elements of identity are historical memories. ${ }^{7}$ How to address different memories of communities is one of key issues for integration of various communities within the EU. Shared European identity and memory should be understood as a collective product of equal actions, of which actions on the authorities' level are particularly important. They were as well in Poland, however it was not made easier by the fact that democratization in Poland gave the authorities and Polish society a long-delayed opportunity to confront its history and its disputes, among which memory of minority groups was one of many memory conflicts which Poland had to cope with. As a result, recent years have witnessed an increased interest in the past, which is expressed by numerous discussions held by political leaders, by representatives of different nations, minority groups and participants in past events. It is particularly visible in the countries of Eastern and Central Europe where memory of the past has a specific context. Political transition resulted in problems with evaluation of the previous system. It also provokes new interpretations of the past. In this case countries, societies and minorities struggle to achieve social consensus as they often tend to present opposite memory views. Participants in past events, their families who belong to different groups and nations have radically different perceptions of the same past events which results in attempts to articulate opposing memory views and cause memory conflicts.

Starting with the nature of what is memory and what distinguishes it from history, according to Maurice Halbwachs, history is singular and objective while memory can multiply. Memory is an ongoing process which develops along with societies. ${ }^{8}$ It is vulnerable to changes, authorities, manipulations and forgetting. It may accommodate selected issues and be affected by individual emotions and attitudes. History on the contrary should be uniform and objective. It is the reconstruction of the past and should be objective and based on documentation. As Maurice Halbwachs argues, the nature of memory is plural and spontaneous, slightly different definition of both terms has been expressed by Pierre Nora, who argues that history:

“(...) belongs to everyone and to no one, whence its claim to universal authority. Memory takes root in the concrete, in spaces, gestures, images, and

\footnotetext{
${ }^{7}$ Ilya Prizel, National Identity and Foreign Policy: Nationalism and Leadership in Poland, Russia and Ukraine (Cambridge: Cambridge University Press, 1998), 2.

${ }^{8}$ Maurice Halbwachs, On Collective Memory (Chicago: The University of Chicago Press, 1992).
} 
objects; history binds itself strictly to temporal continuities, to progressions and to relations between things..."9.

The main purpose of the study is to portray the process in which officials of the state shape the memory and the way they address the plurality of memories. I will assess the importance of authorities in the process of addressing different manifestations of a minority's memories. Discussing politics of memory in relation to minorities in Poland, it is necessary to look at the authorities. The relationship between the authorities and a minority's memories is fundamental to the creation of positive attitudes, recognition and acceptance and to the negotiation of compromises. The primary focus of this thesis is the examination of the role of authorities in shaping politics of memory in relation to the Ukrainian minority. I will discuss the legacy of World War II memories and various ways in which elites in Poland try to deal with the ghosts of the past with regard to the Ukrainian minority. In this context, the research is based on the following questions: how do the Polish authorities address the plurality of memory with regard to Ukrainian minorities? How do Polish authorities react to the demand of minority groups with regard to the recognition of forgotten memories of World War Two ? What does the attitude of the authorities towards minorities' memory tell us about Poland's attitude to the integration of minorities? Poland has strongly institutionalized its version of memory as a country of victims. How did the minorities in a country with a strong memory of victimization voice their own experiences? Memory should be a form of freedom. It is the right of each individual. Should each individual memory be equally protected by the state? Memory is part of our identity. Is there then a line between the claims of collective narrative and claims to preserve the identity of the individual? Is it possible to avoid the existence of censorship within a historical narrative promoted by the state? In other words, can authorities avoid the limitations in the course of history politics or are they a necessity? Do authorities have an interest in shaping memory? Can they have any interests? Are there good and better memories for authorities?

The thesis is based on an assumption that steps undertaken by Polish governmental bodies with regard to the recognition of Ukrainian minority memory were not often consistent. In this process the government attempts to present Poland as an open country, stressing its European character while attempting to distant itself from communist past.

\footnotetext{
${ }^{9}$ Pierre Nora, “Between Memory and History," Representations, no. 26 (1989): 8-9.
} 
However, the discourse of memory politics with regard to the Ukrainian minority is often dominated by the justification strategy. This strategy dominates the Polish debate on memory of World War Two events. It does not deny the crimes committed by Poles against Ukrainians and Ukrainians against Poles but instead it explains that the perpetrators were forced and provoked by fatal and brutal circumstances to commit the crimes. The discourse often underlines that Poles acted in defense and their attacks on Ukrainians were determined by self-defense. Even though memory politics in Poland articulates and admits that Poles murdered many Ukrainian civilians, the Polish discourse of memory politics toward minorities underlines the fault of the opponent as well as communist regime and often minimizes Polish guilt. In order to test this hypothesis, I analyze the steps undertaken by the Polish government in the process of recognition of Ukrainian minority memories on both the international stage as well on the domestic level.

The thesis consists of three chapters. The first presents a brief outline of the memory of Poles. It will be argued that general historical memory of Poles as victims is relevant for majority- minority relations. This section offers a short description of contradictory memories of minority communities in Poland. It underlines and explains the importance of World War Two memories and provides an explanation of conflicting memories of the Ukrainian minority and Polish majority. The second chapter attempts to draw an outline of the political opportunity structure developed on the international level and based on the relations between Ukraine and Poland. This chapter's intent is to portray the relationship between the state and memory by investigating the case of changing opportunities which allowed the emergence of various memories and interpretations of the past. I argue that the emergence of memory regarding the Ukrainian minority is a product of the relationship between Ukraine and Poland. An important question is whether accession to the EU affected the politics of memory toward the Ukrainian minority. The third section is entirely devoted to the Ukrainian minority and Poland's politics of memory on the domestic level. It provides a different understanding of this issue and explains the particular features of this politics towards minorities. I analyze the relationship between the Polish authorities in general and memory of Ukrainian minority. Leaders and authorities at various levels influence the construction of memory politics. The state's authorities organize anniversaries and commemorations; they also erect monuments. They have a monopoly on the sources and symbols which matter for reconciling memory conflicts. I argue that the great responsibility of integrating the minority rests on political authorities through the politics of memory they construct and shape. I will try to assess the 
importance of the authorities in this construction through the examples of major commemorations, monuments and reparations. It is argued that politics of memory with regard to minorities is particularly sensitive. On the one hand it develops a positive pride in Polish history; on the other it carries the risk of producing negative stereotypes and attitudes with regard to minorities.

There are a few theoretical approaches which provide a basis for raising such issues and incorporates memory into politics. Jan Assman claimed that memory exists beyond the experience of generations. ${ }^{10}$ A similar opinion was expressed by Hannah Arendt in "The Human Condition". She underlined that only the political community enables us to sustain memory despite the death of individuals or the disappearance of generations. ${ }^{11}$ According to sociologists such as Rogers Brubaker, political action plays a crucial role in the process of minority identification. ${ }^{12}$ Authorities use a particular language concerned with national identity for which memory is of special importance. The way political actors use it shapes the categorization of a minority. As Michael Ignatieff argues,

"Societies and nations are not like individuals, but their leaders can have an enormous impact on the mysterious process by which individuals come to terms with the painfulness of their societies' past. Leaders give their societies permission to say the unsayable, to think the unthinkable, to rise to gestures of reconciliation that people, individually, cannot imagine" ${ }^{, 13}$.

In Polish political discourse memory policy has been examined and has gained increasing attention with the introduction of a democratic political system. In this new political environment lifting the legal limitations which had been present during communist times provided the opportunity for debate on the role of the state in shaping the historical consciousness of Poles. Many scholars, historians and philosophers have investigated this topic with regard to different memories and memory groups. Among other things, memory politics was presented as a determining factor of political actors in striving for

\footnotetext{
10 Jan Assmann, "Collective Memory and Cultural Identity," New German Critique, no. 65 (1995): 125-126.

${ }^{11}$ Hannah Arendt, Kondycja Ludzka (Warsaw: Fundacja Aletheja, 2000), 13.

${ }^{12}$ Rogers Brubaker, Nationalism reframed: nationhood and the national question in the New Europe (New York: Cambridge University Press, 1996), 103-104.

${ }^{13}$ Michael Ignatieff, The Warrior's Honor: Ethnic War and the Modern Conscience (London: Chatto\&Windus, 1998), 188.
} 
domination of their own political party. One example was a division into post-Solidarity and post-communist political formations. The continuous attempts to present the collective guilt of the post- communists and their ugly communist past were meant to strengthen the power of the post-Solidarity movements. The concept of memory policy caused several controversies in Poland, especially when it started to be used as a political tool. The politics of memory was also presented as tool which could consolidate society. Such a perception was, for example, manifested in the article of Dariusz Gawin " The Community of the Past". $\mathrm{He}$ argued that it is impossible to establish political order without a means to affirm collective identity, of which the most important was the past. ${ }^{14}$ A similar opinion was shared by Tomasz Merta. He emphasized that memory politics must be based on conscious choice and it must stress the historical content to the public. However, in Merta's opinion this content should be determined by positive historical experiences. He underlined the regulatory function of the state's authorities, particularly their role to make decisions with regard to the past. He claims that authorities should stress the positive aspects of the past as only those that consolidate society. ${ }^{15}$ The dominant element of the voices critical of these approaches was concern whether such memory politics would create an accurate picture of history. The opponents of such approaches such as Maciej Janowski or Adam Leszczyński underlined that the function of history and memory is not to consolidate the society but rather to help people to understand the world in which they live. According to them selective memory and the idealization of the history will transform memory and history into propaganda tools. ${ }^{16}$

This study draws on various primary and secondary sources such as reports covering the policy-making process, articles, academic sources, and public statements. Important for my analysis are scholarly examinations on topics of current means of memory production and representation such as cultural institutions, monuments and commemorations, as well as prejudices of Polish society, not to mention surveys of public opinion in relation to the memory of Poles. Despite the popularity of policy issues relating to memory, particularly memory after Communism, there is lack of studies on national minorities and memory about them, especially in Poland. This analysis uses the works and studies of historians who describe the practices which reinforce or change the content of memory. It features articles

\footnotetext{
${ }^{14}$ Dariusz Gawin, „Wspólnota Przeszłości,” Rzeczpospolita, October 7, 2006.

${ }^{15}$ Tomasz Merta, „Polityka historyczna to obowiązek państwa,” Dziennik, June 29, 2006.

${ }^{16}$ Maciej Janowski, „Narodowa megalomania i jej manifestacje,” Przeglqd Polityczny, no.78, 2006.
} 
which appeared mainly in the pages of Rzeczpospolita and Gazeta Wyborcza, as well as scholarly articles related to the policy-making process in the shaping of Polish memory. 


\section{Chapter 1: Changes of 1989 and the Polish Memory.}

This chapter provides a general portrayal of memory in Poland. It briefly describes how the memory developed following changes of 1989. Even though Poland is described as a homogeneous country, it consists of many regional communities which differ from each other by culture and customs but mostly by memory. It will be underlined that Poland, apart from the mainstream memory, is divided into several communities of memory. Of greatest importance are memories of World War II. Both Poles and minority groups have their own interpretations of particular experiences that are often in conflict with the main Polish narrative. This chapter will define the core of opposing interpretations.

\subsection{The Picture of Memory in Poland}

Interest in the past is reflected in the discussions held by scholars, political leaders and artists. Pierre Nora argues that during this century almost all countries, as well as ethnic and social groups experienced the shock of fundamental change in their relationship with the past. ${ }^{17}$ Such a boom of memory did not leave out Poland. Looking at recent years of political life in Poland, it is easy to observe that memory of the past has become more and more important. The increasing use of the past is visible in media, political discourse and institutions. Before 1989 certain memories were omitted and unrecognized. After 1989, memory became alive again, but was characterized by different and conflicting views of the past.

Before 1989 Poland was a country constituted by two types of memory. The main one belonged to the dominant historical narrative of the political and cultural life of Poles. It was revealed through museums, the state's organized public events, and education in the schools. The past, history, memory were all part of ideological propaganda which was strengthened by the vision of a homogenous country. It was mainly based on common postwar sense of injustice caused by Germans. In post- war years many topics were suppressed by censorship and fell into oblivion. To a large degree it concerned topics with regard to Soviet crimes and

\footnotetext{
${ }^{17}$ Jacek Żakowski, „Epoka Upamiętnienia. Rozmowy z Pierre’em Nora,” in Rewanż Pamięci, Jacek Żakowski ( Warsaw: Wydawnictwo Sic!, 2002), 59.
} 
crimes committed by the Security Service of the Ministry of Internal Affairs (Stużba Bezpieczeństwa Ministerstwa Spraw Wewnętrznych). ${ }^{18}$ Soviet aggression of September 17 or the massacre in Katyń were just couple of examples of such white spots- this term described events that were censored by the communist authorities. Nevertheless it was not easy to suppress the entire memory. The other memory was unofficial and at the same time forbidden. It existed only through personal and individual interactions. Preventing censorship of memory has been difficult, but possible. Important for forbidden memory was emigration and émigré institutions which smuggled many books and magazines to Poland and kept forbidden memory alive. The removal of censorship became one of the main activities and goals of the opposition which published underground press, books and magazines.

The quality of memory changed after Poland's democratic revolution in 1989. The post-1989 transition revealed the memories of different groups in Poland. As a result the intensity of public debate over relations with other countries increased. Nevertheless there was and still is a visible tendency to emphasize the martyrdom of the Poles which makes it difficult for Poles to accept that they could cause suffering of others. This memory discourse is dominated by the portrait of Poles as a great nation, characterized by heroism and bravery. The typical Polish hero always fights for noble reasons, even though he is always doomed to failure. So in the end he would never be called a loser but someone with a pure soul who devotes his life to his country. ${ }^{19}$ History often tends to be idealized, which is always unfortunate but at the same time it is always heroic history that retains great popular appeal. There is an exaggerated idealization of history but on the other hand there is as well a tendency to "desacralize" Polish history by pointing at shameful events and by emphasizing Polish historical grievances.

The memory of World War II is of special importance. It raises the most controversy and emotions. Most Poles believe in their collective heroism and, that of all the nations, they had suffered the most. The survey on memory and knowledge of Poles conducted in 2009 by Pentor for the World War II Museum confirms this belief. Survey results show a general pride in Polish war heroes such as Gen. Władysław Anders, Władysław Sikorski or

\footnotetext{
${ }^{18}$ Security Service of the Ministry of Internal Affairs or SB was the security organ of Polish People's Republic. It controlled all possible structures of social life in Poland as well as abroad. Its activity was based on its main goal which was the protection of the communist system in Poland.

${ }^{19}$ Lech M. Nijakowski, Polska polityka pamięci, esej socjologiczny (Warsaw: Wydawnictwa Akademickie i Porfesjonalne, 2008), 190-200.
} 
Maksymilian Kolbe. Respondents worship the 1944 Warsaw Uprising and resistance during the1939 September campaign but they are reluctant to acknowledge any event that brings shame to the Poles. Only $17 \%$ of respondents said that there were such experiences ${ }^{20}$ For the Poles history is mainly a source of glory. In a survey conducted in 1965 only $4.5 \%$ of the Poles admitted that there were experiences in World War II which bring shame to the Poles. This survey was repeated in 2003 and the same statement was confirmed by $4.4 \%$ of respondents. $^{21}$

\subsection{The Communities of Memory}

What may influence the hierarchy of memories mentioned above are the proportions between the majority and minority populations in Poland. Before World War II Poland was a multicultural country. Almost one third of the population belonged to national and ethnic minorities. The experience of World War II changed the cultural map of Poland. The multiethnic population of Poland, with particularly its significant Jewish community, had disappeared from the European map. What is more, later years showed that the ethnic politics of the communist government were designed to create a country of one nation. Looking at the results of the most recent National Census, contemporary Poland maintains this monoethnic profile. According to the National Census of Population and Housing of 2002, only $1.2 \%$ of respondents declared a non-Polish identity. $2 \%$ were not able to identify their nationality while $96.7 \%$ of respondents declared themselves as Polish. ${ }^{22}$ Nevertheless, after 1989 this small percentage of $1.2 \%$ consisted of Germans, Ukrainians, Lemkos, Jews, Lithuanians and many others who were able to disrupt the dominant Polish memory and mark their own memories.

The transition after 1989 revealed the memories of different minority groups. A number of memories emerged. Memories of minority groups returned into the public and official discourse of Poland. Smaller groups gained the right and possibility to express their views of the past. The role of civil society and NGOs at this point gained importance. The

\footnotetext{
${ }^{20}$ Pentor, „Poplątana pamięć o II wojnie,” Tns Pentor, 2009, http://www.pentor.pl/58419.xml?doc id=11280 (accessed September 21, 2011).

${ }^{21}$ Barbara Szacka, Czas przeszły, pamięć, mit (Warsaw: Wydawnictwo Naukowe Scholar, 2006), 161-162.

${ }^{22}$ Kazimierz Szczygielski, Geografia Mniejszości Narodowych i Etnicznych w Polsce. Ujęcie ilościowe (Opole: Wydawnictwo Instytut Śląski, 2008), 27.
} 
memory propaganda of the communist state was replaced by the pluralization of memories. Such democratization of memory in Poland opened up the new opportunities of participation in the construction of memory of the past.

An important aspect of a minority' s exclusion in Poland is a deep sense of lack of public recognition of their different history, related primarily to other interpretations of the Polish events of World War II. Each of these debates has its own dynamic and complexities. Democratic changes determined the revision of the past and demanded taking an attitude towards different interpretations of the past experiences formulated by representatives of various groups. It became a challenging process for Poles and their memory of a heroic nation which suffered the most during World War II as it raised questions of who was the perpetrator and who was a victim. Since Poles portrayed themselves as victims and demanded compensation from other countries, the reverse situation in which citizens or representatives of different nations submit claims against the Polish state became a big challenge for Poland. The exposure of different interpretations resulted in the listing of injustices experienced by particular communities which in the end became a reason for political or financial claims. Such demands are addressed and directed toward the state and in this way memory conflicts stepped into the realm of politics. ${ }^{23}$ Lemkos and Ukrainians expect condemnation of Action Vistula, which removed them from their homelands after the war, recognition of the moral consequences of their resettlement and return of property. The German minority expects public recognition of their presence and German culture in Silesia. A central problem is the regulation of property left by persons who left for Germany. These are mainly estates on the western and northern Polish territories. There is also intensive debate over the expulsions of Germans as a result of World War Two. For Lithuanians a contentious issue is the interwar period. Central to it is a dispute about the boundary between Poland and Lithuania in 19191920. For the representatives of the Jewish community, memory of World War II, the first postwar years, and March 1968 play an important role. For a long time violence of the Polish society against the Jews were a forgotten subject. The book of Jan T. Gross published in 2000, about the murder of Jewish community in Jedwabne by their Polish neighbors, launched a debate on Polish- Jewish relations and anti-Jewish prejudices in Poland. ${ }^{24}$

\footnotetext{
${ }^{23}$ Jacek Żakowski, Rewanż pamięci (Warsaw: Wydawnictwo Sic!, 2002), 33-34.

${ }^{24}$ The book „Neighbors: The Destruction of the Jewish Community in Jedwabne, Poland” by Jan T. Gross explores the 1941 massacre in Jedwabne against Polish Jews. The book gives an account of the massacre
} 
Ethnic and national minorities in Poland constitute minority communities of memory. Their memory of the past is different from the majority's memory narrative promoted by the state. To retain memory which is different than the majority one is very difficult. That's why the state's politics of memory is of special importance. It is necessary to remember that such politics is a extremely difficult area because of the responsibility it implies. On the one hand one kind of politics of memory can protect a national memory, while building a positive image of the state's actions. On the other, it may strengthen negative stereotypes of a minority group. The opposing historical interpretations of minority groups can be considered as evil or hostile memory. This is why the politics of memory toward minorities is very important and, moreover, it requires from authorities particular sensitivity and knowledge.

\subsection{The Ukrainian community of memory- what determines their memory? Crimes of World War II and postwar years.}

Claims made by the Ukrainian minority in Poland are concerned with the events in the past. For this reason a analysis of their memory requires a historical inquiry. This section offers an introduction into conflicting memories between Poland and Ukraine. It focuses on the displacement campaigns during World War Two and shortly thereafter. The memories of most controversy in Polish-Ukrainian relations are the memory of Action Vistula on the one hand and Massacre of Poles in Volhynia on the other. In the case of these two memories both parties struggle to reconcile their separate points of view.

The history of both the Polish and Ukrainian nations abounds with conflicts and wars over several centuries. However, of greatest importance for shaping the contemporary memory conflicts between Poland and its Ukrainian minority was the experience of the second half of the twentieth century. The source of its conflicts are the crimes committed on the territory of Volhynia and Galicia during World War II and the postwar years. In terms of Polish-Ukrainian relations central was their conflict over the dominance of these regions inhabited by both nations. Vital for the recognition of Ukrainian memory is the memory of forced expulsion of post war Poland's Ukrainian minority. However to analyze the memory of

committed entirely by Poles on Jewish community of Jedwabne and brought a lot of attention to Polish- Jewish relations. 
this experience it is necessary to take into account the massacres of the Poles in Volhynia and Eastern Galicia which peaked between 1943 and 1944.

The causes of the conflicts between Poland and Ukraine go back to the years before 1943.The history of Polish- Ukrainian relations was shaped by centuries. To a great extent, it determined the place of Ukrainians in Polish public awareness. It is necessary to remember that during the inter-war period, Poland contained of 3-4 million Ukrainians. They constituted more than $10 \%$ of all citizens of the country. ${ }^{25}$ Even though the March Constitution of 1921, guaranteed to all Polish citizens equal rights regardless of nationality and religion, the national minorities were treated as a second-class citizens. This did not facilitate peaceful coexistence between Poles and Ukrainians. During the period when Poland was restored as independent state the idea of the nation- state dominated political discourse. It resulted in politics of discrimination against national minorities and deepened the conflicts between Poles and Ukrainians. What is more, the ethnic differentiation was strengthened by the social divisions in Poland. Ukrainians mostly inhabited small villages as peasants while Poles were usually property owners. ${ }^{26}$ With the outbreak of World War Two, Poles and Ukrainians found themselves in a different geopolitical situation. Poland considered Germans as the main enemy, while the Soviets were the enemy number two. Meanwhile Ukrainians considered Germany as a country that was interested in their independence. Particularly for western Ukraine the Soviets were the central enemy, followed by Poland as enemy number two. Such negative perceptions of both countries were determined by the earlier experience of Ukraine's partition between the two states.

After World War One Poland returned to the European map as the independent country. Politicians as well as historians agree that Polish state policy of the interwar period had a great influence on the development of the wartime and postwar Polish-Ukrainian conflict. They agree that it had a negative impact on relations between two countries; however, they deny that it could cause such radical actions of ethnic cleansing on the Ukrainian side between 1943-1944. What is underlined by historians is the importance of Volhynia and Galicia as territories for Ukrainian elites to build an independent Ukraine. The idea of removing Poles from the contested territories was born already in 1907. Many

\footnotetext{
${ }^{25}$ Grzegorz Motyka, Ukraińska Partyzantka 1942- 1960 (Warsaw: Instytut Pamięci Narodowej, 2006), 7.

${ }^{26}$ Paweł Kowal, Jan Ołdakowski and Monika Zuchniak, Nie jesteśmy Ukrainofilami. Polska myśl polityczna wobec Ukraińców i Ukrainy (Wrocław: Kolegium Europy Wschodniej, 2003), 7-28.
} 
Ukrainian politicians of that time shared the common opinion that people of two different nations cannot live on the same territory. The experience of 1914-1939, especially defeat in the Polish-Ukrainian War between 1918 and 1919 for the domination over Eastern Galicia territory, brought them to the conclusion that compromise with the Poles was impossible and they decided to implement their former slogan "Poles behind San" (Lachy za San) and force Poles to leave the territory of Volhynia and Galicia. ${ }^{27}$

Central to these actions and to the later memories of Poles and Ukrainians is the Ukrainian Insurgent Army. This force was created in 1939 as a radical nationalist organization based on the mobilization of individuals to the cause of an independent Ukraine. $^{28}$ It was created as a result of the Organization of Ukrainian Nationalists' (OUN) split into two factions named after the leaders: Stepan Bandera and Andriy Melnyk. Between 1942-1945 the banderowcy joined the partisan formation which took the name of the Ukrainian Insurgent Army (UPA). ${ }^{29}$ The Ukrainian Insurgent Army was hostile to Poland from the beginning. Firstly, because of tensions stemming from interwar period, strengthened by the Polish national policy toward Ukraine; and secondly, because of a strongly nationalist ideology of the organization. This formation from the beginning carried out anti-Polish ethnic cleansing. At the turn of 1942/1943 they decided to expel all Poles living in the disputed lands in order to obtain a purified national territory. The period between 1943- 1944 is considered as the apogee of the conflict between Poles and Ukrainians on the territory of Galicia and Volhynia. The anti-Polish actions started already in 1942 but they gained strength in 1943. Most attacks took place on July 11, 1943. The activities of the Ukrainian partisans varied from place to place, nevertheless the methods of ethnic cleansing were very cruel. The policy of mass killings of Poles adopted by the Ukrainian Insurgent Army between 1943-1944 led to a massacre of over 100 thousand civilians. ${ }^{30}$

\footnotetext{
${ }^{27}$ Grzegorz Motyka and Dariusz Libionka, Antypolska Akcja OUN-UPA 1943-1944, Fakty i Interpretacje (Warsaw: Instytut Pamięci Narodowej, 2002), 14-18.

${ }^{28}$ Motyka, Antypolska Akcja OUN-UPA 1943-1944, 41.

${ }^{29}$ Banderowcy, is a term used by Ukrainians to describe supporters of Stepan Bandera who led to the split of OUN and created their own faction - the OUN -B. Poles used this term to describe all Ukrainians who took part in mass murders.

${ }^{30}$ It is unknown how many Polish people died as a result of the OUN- UPA ethnic cleansing. The estimates run from 50, 000 to 500, 000. However many historians indicate the number of 100, 000. For a more extended discussion into the Volhyn massacre see, Tadeusz Piotrkowski, Poland's Holocaust: Ethnic Strife, Collaboration with Occupying Forces and Genocide in the Second Republic, 1918-1947 (Jefferson: McFarland and Company, 1997).
} 
A part of the Ukrainian community did not support the actions of Bandera. However, after 1945 the Polish People's Republic focused on the removal of Ukrainians living inside Poland's postwar borders.. Displacement of the Ukrainian population was the result of an agreement concluded on 9 September 1944 between the Polish Committee of National Liberation (Polski Komitet Wyzwolenia Narodowego, PKWN) and the USSR. Ukrainians had to leave Poland and the Poles were to leave the USSR. According to official data for the period 1944-1946, 789,000 Poles left the USSR while 488,000 Ukrainians left Poland. ${ }^{31}$

In 1944 Poland lost its sovereignty and became a country under a strong influence of the Soviet Union. At the Yalta Conference in February 1945 Stalin agreed to form a coalition government in Poland. However, Communists dominated the new Polish government so with the support from the Soviet Union they controlled all elections and quickly expanded their control over the country. The election of 1947 ended up with official results of victory for Communist- dominated Democratic Bloc and marked the beginning of the Republic of Poland under the control of Communists. The Polish Communists decided to deal with UPA after the rigging of elections to the Sejm and destroying the Polish underground forces. ${ }^{32}$ Action Vistula was launched on April 28, 1947. It resulted in the mass deportation and dispersion of Ukrainian population to the "regained territories" of Poland. ${ }^{33}$ Shortly after World War Two, in agreement with the Soviet Union, Polish Communist authorities planned the resettlement of Ukrainians from southeast Poland into the Ukraine. The southeastern part of Poland was inhabited by almost 700 thousand Ukrainians and Lemkos. In the beginning such migrations were voluntary. However when authorities realized that not many people voluntarily moved to the Soviet-controlled Ukraine, they decided to use force. Deportations were conducted mainly by the Poles, with the majority of people coming from the former borderlands who were motivated by feelings of revenge and hatred toward Ukrainians after the massacre of Poles in Volhynia. As a result, the deportations were very brutal. Almost 480 thousand people were displaced. Nevertheless it did not satisfy the communist authorities. They still perceived the remaining Ukrainians as a danger to the Polish state. Consequently, in 1947 almost 150 thousand of Ukrainians and Lemkos were resettled from the three south eastern provinces of Poland into the so called Recovered Territories (Ziemie Odzyskane) of

\footnotetext{
${ }^{31}$ Philipp Ther and Ana Siljak, 161-162.

${ }^{32}$ The Sejm is the lower house of the Polish parliament.

${ }^{33}$ Regained Territories or Recovered Territories ( Ziemie Odzyskane), is a term used to describe parts of pre-war Germany which became part of Poland after WWII.
} 
Poland in the west. Between April and July of 1947 Ukrainians were resettled into mainly the northern part of Poland. The authorities tried to avoid any consolidation of Ukrainians and Lemkos by dispersing them. ${ }^{34}$

For the communists, forced resettlement of Ukrainians and Lemkos was supposed to solve the issue of Ukrainians in Poland . Displaced people were subjected to total control. In official documents they were not described as Ukrainians, but "settlers from the Action Vistula". ${ }^{35}$

As the result of Polish-Ukrainian conflict between 1942-1947 around 100 thousand Poles were killed and 10-15 thousand Ukrainians. This tragedy constantly recurs in the Polish-Ukrainian debates about history. In the past 20 years much has occurred in the shaping of historical memory of both the Poles and Ukrainians. This is even more important since different assessments of the past remain an important factor which troubles cooperation between Poland and Ukraine.

The Volhynia massacre in particular created the image of Ukrainians as nationalists, fascists and murderers. The experience of 1943- 1944 developed a strong negative image of Ukrainians with the particular focus on the Ukrainian Insurgent Army. In the Polish mentality of that time, Ukrainians were considered as a source of danger which was further strengthened in the communist era because there was no discussion and no studies of the dramatic events of the war. Memory was only passed on orally form from those who survived. Because of fact that Poland was satellite country of the Soviet Union and Ukraine one of its parts, real discussion on the past in both countries was impossible. Some of the negative perceptions of Ukrainians have survived to this day in contemporary Poland. Such negative depictions of Ukrainians as fascists and murderers could be easily found on graffiti in Przemyśl in the 1990s or in protests against the UPA's memorials in more recent years.

\footnotetext{
34 Timothy Snyder, "To Resolve the Ukrainian Problem Once and for All. The Ethnic Cleansing of Ukrainians in Poland, 1943-1947,"Journal of Cold War Studies 1.2 (1999):86-120.

${ }^{35}$ Igor Hałagida, "Pierwsze lata Ukraińców na zachodnich i północnych ziemiach Polski po przesiedleniu w ramach akcji „Wisła”," in Akcja Wisła, ed. Jan Pisuliński (Warsaw: IPN, 2003), 132.
} 


\subsection{Conflicting interpretations}

The Communist government strengthened the portrayal of Ukrainians as fascists. According to the Communist authorities, the state's harsh actions were in response to the Ukrainian Insurgent Army's (UPA) policy of murdering Poles of Volhynia and Eastern Galicia. Officially the campaign against Ukrainians was explained by the need to stop the activity of UPA. Some historians claim that the campaign was organized on orders coming from Moscow whose leadership conducted anti-UPA operations east of the Polish border as well. Even if true, such an explanation removes the guilt of Poles. Another interpretation says that the expulsions were initiated by Communists of Poland with the support of Moscow which was supposed to legitimize the rule of the Communist authorities. Many historians claim that Operation Vistula was not necessary to suppress the UPA. However, according to many Poles, it was the result of Ukrainians' brutal massacre of Poles and anti-Polish crimes committed by UPA. Many disputes over this matter emerged after 1989. There are two major approaches. Some historians, supported by Grzegorz Motyka or by Roman Drozd, describe Operation Vistula as the unjustified repression of Ukrainians by the communist regime against Ukrainians. Their main argument is that the method used by the government of that time was not proportional to the risk coming from the Ukrainian Insurgent Army. A second group of historians such as Ewa Siemaszko or Marek Jasiak recognize the displacement actions as a necessary measure in order to stop the Ukrainian Insurgent Army and to prevent destabilization in the disputed southeastern regions. They underline that the Communist character of government of that time was not central to the situation and the undertaken actions. $^{36}$

Interpretations which reject the responsibility of one's own side exist both in Poland and in Ukraine. Both countries employ opposing narratives of responsibility for the violence. The memory of ethnic-cleansing and competition between narratives of both countries have to some extent influenced further relations between Poland and Ukraine.

\footnotetext{
${ }^{36}$ Grzegorz. Motyka, „Problematyka stosunków polsko-ukraińskich w latach 1939-1948 w polskiej historiografii po roku 1989," in Historycy polscy i ukraińscy wobec problemów XX wieku, ed. Piotr Kosiewski, Grzegorz Motyka, (Kraków, Forum Europy Środkowo-Wschodniej, 2000), 166-178.
} 


\section{Chapter 2 Political opportunity structure}

This chapter discusses the relationship between the state and memory by investigating the changing opportunities which allowed the emergence of various forms of minority activism with regards to their memory and interpretations of the past. I argue that memory is also an argument in international forums and as a result the emergence of Ukrainian minority memory activism is a product of the relationship between Ukraine and Poland. As Tarrow argues, institutional and political elements can bring to social movements opportunities to legitimate their needs. ${ }^{37}$ This chapter will analyze whether Poland has developed the legal framework and institutions which enable the recognition of competing memories of minorities. The purpose of this chapter is to portray steps which were undertaken after 1989 by the Polish government in order to develop a legal framework for the integration of minorities in the international context, particularly in the context of interstate relations between Poland and Ukraine. It addresses the question of European enlargement and tries to analyze if enlargement of the EU has affected the politics of memory toward minorities.

The power of memory has real forms including specific legislative acts, agreements or decisions. Did it mean that minorities gained another opportunity to voice their historical grievances? Did the international context change anything? The organization of this chapter is base on time frames. In the beginning I provide a brief description of opportunities delivered by the communist state before 1989. Then the next part is focused on early years of democratic transformation in Poland until 1993 when Poland experienced some problems with regard to the transformation. These problems are addressed in the third section when early parliamentary elections were held and the political party of ex-communists took power. The last part provides an outline of the years after 1994 since they are considered as a time when the relationship between two countries improved.

\footnotetext{
${ }^{37}$ Sidney Tarrow, Power in Movement: Social Movements, Collective Actions and Politics (New York: Cambridge University Press, 1994), 251-252.
} 


\subsection{Political opportunity structure after 1945}

In Poland, of particular importance were the effects of World War II. The Polish society was supposed to become ethnically homogeneous in order to get rid of "internal enemies". To achieve it, forced deportations of Germans and Ukrainians were conducted, and other limitations on minorities' activities were introduced. Ethnic homogeneity and the resulting national unity was considered one of the major achievements of the new socialist state. This corresponded with new legal regulation. In both the Constitution of 1952 and other legislation the term national minority did not exist. ${ }^{38}$ Characteristic of the state's policy towards national minorities after 1945 was, on the one hand the limited right to maintain a separate identity, and on the other hand the exclusion of minorities from the public sphere and pressure for their assimilation as a means of social integration. The public possibility to express non-Polish ethnicity was impossible. National minorities had right to maintain their local culture, however it was allowed in a way that kept it invisible to the rest of Polish society. ${ }^{39}$ The authorities sought to destroy the memory of the presence of national minorities by, for example, renaming the streets which sounded too Ukrainian. In communist Poland, after Action Vistula the use of native language by Ukrainians was forbidden and they were not allowed to change their place of residence. The number of displaced Ukrainians in every village could not exceed $10 \%$ of the total population. Those who did not comply with the above prohibitions were repressed. Ukrainians who attempted to return to their homelands were punished by resettlement to the former Nazi camp in Jaworzno. ${ }^{40}$ The Ukrainian minority did not exist even in the statistics. Instead of using the term "Ukrainian" to describe a person of Ukrainian ancestry, authorities were using the phrase "resettled in Action Vistula".

When 1956 brought a thaw, the Ukrainian Socio-Cultural Society (Ukrainskie Towarzystwo Społeczno- Kulturalne) started slowly to renew its activities. Some of Ukrainians from the northern and western territories of Poland were allowed to return to their homelands. Additionally, in educational institutions the Ukrainian language started to be used

\footnotetext{
${ }^{38}$ Sławomir Łodziński, The Protection of National and Ethnic Minorities in Poland after 1989 (Warsaw: Ministry of Foreign Affair, 2002), 15.

${ }^{39}$ Henryk Chałupczak and Tomasz Browarek, Mniejszości narodowe w Polsce: 1918-1995 (Lublin: Wydawnictwo UMSC, 1998),87.

40 Jarosław Hrycak, Historia Ukrainy 1772-1999. Narodziny nowoczesnego narodu (Lublin: Instytut Europy Środkowo- Wschodniej, 2000),279
} 
and Greek Catholic parishes were formed. ${ }^{41}$ A more liberal policy was conducted also with regard to other minorities. Still, however, expressions of "Ukrainian nationalism" were ruthlessly suppressed. The return to the homeland was still difficult. The People of Action Vistula were under control of authorities in Poland until the 1990s. As a result of the Action Vistula, the Ukrainian minority in Poland remains dispersed. Only in nine communities in Poland do Ukrainians make up more than $10 \%$ of the population. Most of Ukrainians were settled in the Recovered Territories in the then called provinces of Wrocław, Olsztyn, Zielona Góra, Koszalin, Gdańsk and Szczecin. Some who were able to return remained in the provinces of Kraków, Rzeszów, Białystok and Lublin. The communists controlled all publications and banned any research which would disclose certain facts of Ukrainian's past. In 1956 the Ukrainian Socio- Cultural Society was established as a result of limited democratization resulted from thaw of $1956 .{ }^{42}$ And it was linked to the new Communist Party program, adopted during the Seventh Plenum when all artificial fragmentation and division according to ethnic origin and all signs of discrimination were condemned. ${ }^{43}$ At the beginning of the 1980s a few Catholic journals such as Znak, Więź and Tygodnik Powszechny as well as the leading Polish emigré journal Kultura called for friendship between Poland and Ukraine as an idea and way to protect Poland from Soviet influence. ${ }^{44}$ The idea did not receive much attention at that time, however a few years later minority activists returned to this subject. In 1989 The Committee for Cooperation with the National Minorities ( Komisja Wspótpracy z Mniejszościami Narodowymi) was established as a result of an appeal to Lech Wałęsa to discuss issues of minorities during the Round Table discussions. ${ }^{45}$ It was requested by Jacek Kuroń, , Bogdan Skaradzińskie, Włodzimierz Mokry and many others. The latter was the first representative of the Ukrainian minority who became a deputy in Polish lower house (Sejm).

\footnotetext{
${ }^{41}$ Mirosław Czech, “Kwestia ukraińska w III Rzeczypospolitej,”Ukraińcy w Polsce 1989-1993, ed. Mirosław Czech (Warsaw, Związek Ukraińców w Polsce, 1993), 269.

${ }^{42}$ The Thaw was a term used to describe change in the Polish political stage in the end of 1956. The death of the leader of Soviet Union, Joseph Stalin and the Polish communist leader Bolesław Bierut weakened the communist faction in Poland. Another term used to describe this change is "Polish October".

${ }^{43}$ Roman Drozd and Igor Hałagida, Ukraińcy w Polsce 1944- 1989. Walka o Tożsamość( Warsaw: Burchard Edition,1999), 82-88.

${ }^{44}$ Robert Kostrzewa, Between East and West, Writing from Kultura (New York, Hill and Wang, 1990), 18-19.

${ }^{45}$ The Polish Round Table discussions took place in Warsaw on 6 February to 4 April of 1989. The discussions were held between the government and banned trade union Solidarność. Round Table Talks are considered as the pivotal moment for the fall of communism and the beginning of democratic transition in Poland.
} 
The anti-Ukrainian sentiment promoted by the communist government lost its intensity after 1989, but after the end of World War II it must have appeared that the wall which was erected between Ukraine and Poland would never be destroyed. Historical recalcitrance and hostility were the major elements in shaping mutual perceptions. The main obstacle to agreement was the negative historical memory. With such a huge burden of the past it was impossible to just forget and leave history behind, which actually the communist government attempted to do. After World War Two Ukraine was a Soviet Republic. This is why it did not conduct its own foreign policy. All contacts, including those with Poland, were controlled by Moscow. The communist regime tried to control the shape of Polish-Ukrainian relations. Dealing with history was not possible and not allowed. Until 1989 Moscow tried to have full control over what was happening on the border of Ukraine and Poland. Cultural and economic cooperation between Poland and the Ukrainian Soviet Republic was very limited. ${ }^{46}$ The Soviet Union not only was opposed to friendly relations between Poland and Ukraine, but as well did not want to discuss conflicting memories of both countries. In this way the Soviet communist regime strengthened the negative stereotypes with regard to Poles. Pre-communist Poland was presented as a perpetrator of everything bad that had ever happened to Ukraine. ${ }^{47}$ A similar situation was on the Polish side. The People's Republic of Poland continuously created the negative image of Ukrainians. Words such as Ukrainian was used as a replacement for description of the enemy of Poland. During the initial years of the postwar period, victims were afraid of arrest and deportation and therefore preferred not to speak publicly about their rights and demands.

\subsection{Changes of 1989}

After 1989 there was an increase in the social visibility of the ethnic and national diversity within Polish society. Democratic political changes gave the representatives of national and ethnic minorities an opportunity to freely express their ethnic identity and conduct public activities, which was already noted by Tadeusz Mazowiecki during his inaugural parliamentary speech in 1989. He emphasized that Poland was just as much a

\footnotetext{
${ }^{46}$ Włodzimierz Bonusiak, Polska- Niemcy- Ukraina w Europie. Uwarunkowania, założenia i przesłanki wzajemnej współpracy (Rzeszów: WSP, 1996), 200.

${ }^{47}$ Stephen R. Burant, Problematyka Wschodnia. Studium porównawcze stosunków Polski z Litwq, Białorusiq i Ukrainq ( Warsaw: The Polish Institute of International Affairs, 1993), 15.
} 
homeland for national minorities as for ethnic Poles. ${ }^{48}$ Moreover, 1989 changed the whole political system of reference, through the emergence of new institutions and situations in which minority activities could occur in public.

After 1989 the democratic changes in Poland introduced the rule of law and protection of human rights, which gave the representatives of nations different than Polish a chance to freely express their national and ethnic identity. Secondly, the implementation of Polish aspirations for integration with Western organizations such as the North Atlantic Treaty Organization (NATO) and the EU had to be associated with solutions with regard to the protection of minorities. The establishment of appropriate national policy was therefore to be treated somehow as a part of the reconstruction process of sovereign Poland, its democratic system and the desire to integrate into European and NATO structures. Relation with minorities became a component of the recognition of pluralism in building a liberal democracy.

The Ukrainian community in Poland was reborn. It created a number of social organizations. Ukrainians have their own programs in broadcast media such as "Telenowyny," given once a month on TV Info. There is as well Ukrainian newspapers (including the "Our Word"). Preservation of their identity became the key challenge, because Ukrainians were scattered over the country.

The question of Polish-Ukrainian memory aroused increasing interest in the development of mutual relations based on common past. On 3 August 1990 the Senate of the Republic of Poland adopted a resolution which condemned the Action Vistula under which many Ukrainians, Lemkos and Boykos were expelled from the southeastern territories of Poland. This gesture was positively received in Ukraine and improved the trust between the two countries.

On 18 May 1992 Poland decided to strengthen cooperation with Ukraine by signing The Treaty of Good Neighborliness and Friendly Cooperation. ${ }^{49}$ Preparation of this document lasted four months. As an international document of the highest rank it was signed by the

\footnotetext{
${ }^{48}$ Sławomir Łodziński, 16.

${ }^{49}$ Traktat o dobrym sąsiedztwie, przyjaznych stosunkach i współpracy, Warsaw, 18.05.1992, Dz.U.1993, nr. 125, poz. 573.
} 
president of Poland Lech Walesa and president of Ukraine Leonid Krawczuk for a period of fifteen years. This is the most important Polish-Ukrainian agreement, under which Poland and Ukraine as two independent countries acknowledged a common border, territorial integrity and excluded the use of force. An important issue was to grant rights to the members of national minorities - the Polish minority in Ukraine and Ukrainians in Poland. In Article 11 of the Treaty the two countries guarantee the right of the Polish and Ukrainian minorities to preserve, express and develop their ethnic, cultural, linguistic and religious identity. A new element was an agreement to finance social and cultural organizations by the home country. Both countries ratified the Treaty, however the Ukrainian parliament considered suspension of treaty's ratification till the lower house of the Polish parliament (Sejm) condemned the Action Vistula. For Poland this document was a perfect reflection of Foreign Minister Skubiszewski's two-track policy, the challenge of which was on the one hand the integration with international structures of the West and, on the other hand, peaceful relations with Eastern neighboring countries. The Treaty was an important tool, both in relations with the West and Russia. In this way, Poland hoped to show that there were no concerns about potential ethnic and territorial disputes that could stand in their the way to joining to EU.

Poland and Ukraine recognized the role and importance of developing media activities and in the same year both countries initiated cooperation between their state radio and television networks. A respective agreement, which allowed for the free exchange of radio and television political, cultural and scientific programs was signed. ${ }^{50}$

The years of 1989-1992 were the initial stage of post-communist era in PolishUkrainian relations. It was an important period for creating the necessary institutional basis for cooperation between both countries. It established the legal and procedural basis for mutual actions.

\subsection{The problems of 1993}

In 1993, on of 12 and 13 January, the Polish Prime Minister Hanna Suchocka visited Ukraine. This visit initiated the next stage in the Polish-Ukrainian relations. It was a working

\footnotetext{
${ }^{50}$ Umowa o współpracy między Polskim Radiem i Ukraińskim Radiem, Warsaw, 23.10.1992, Umowa o współpracy w dziedzinie telewizji między Telewizja Polską i Teleradiokompanią Ukraińska, Warsaw, 23.10.1992.
} 
visit during which difficult issues, such as the one related to Action Vistula and the antiPolish activities of the Ukrainian Insurgent Army in Western Ukraine were discussed. Those issues threw a shadow on Polish-Ukrainian relations. To overcome it, both sides agreed to establish a joint commission for textbooks in history and geography. However, Suchocka found herself in a political delicate situation on the Action Vistula issue and insisted that, as Poles reviewed the history of World War II, Ukrainians would also have to reevaluate their own conduct in Volhynia and Galicia. ${ }^{51}$ A group of Polish journalists criticized the visit and accused Polish diplomacy of lack of adequate preparation, considering it a serious error to arrive at a time when the President of Ukraine was not in the country but abroad instead. Nevertheless, experts of the Eastern Studies Center stressed that it was just a working visit so the presence of president was not necessary. They claimed that there remained a competent Ukrainian team of politicians on site, having power of attorney granted by the president. According to their opinion the absence of the president did not undermine the importance of this visit.

The purpose of Suchocka's trip to Kiev was to outline a program of cultural and scientific, legal and economic cooperation. It was to be achieved by signing the Preliminary Agreement Between the Government of the Republic of Poland and the Government of Ukraine on cultural and scientific cooperation. In addition, on behalf of the Polish government Suchocka declared support for Ukrainian sovereignty. It had great significance because the declaration was delivered on the eve of the summit of the Commonwealth of Independent States (CIS). In this way, Poland gave a signal to Moscow that it would not agree to a resubordination of the former Soviet republics. Meanwhile, Russia considered independent Ukraine as an artificial state.

During the same visit the Protocol on the Establishment of the Consultative Committee of the Presidents of the Polish and Ukrainian states was signed. This was an initiative of Lech Walesa, accepted with enthusiasm by Ukraine. The Committee was supposed to be one of the most important bodies in the field of international security. An inaugural meeting took place in May 1993. In 1993, Lech Walesa visited Ukraine with the purpose of strengthening Polish-Ukrainian cooperation. The main objective of this visit was to broaden the legal base to facilitate bilateral contacts. Although the visit ended with the

\footnotetext{
${ }^{51}$ Timothy Snyder, The Reconstruction of Nations: Poland, Ukraine, Lithuania, Belarus, 1569-1999 (New Haven, CT: Yale University Press, 2003), 264.
} 
signing of several agreements, the intensive cooperation between the Polish and Ukraine governments came to a quick end. The next committee meeting took place in November, after which it was suspended for two years because of the tense internal situation in Poland. In the autumn of 1993 ex communist parties took over power in Poland as a result of early elections called by Lech Wałęsa following his dissolution of the Sejm. The election results were an outcome of complex issues, however social hardships due to economic transition was at the core of the tense political situation.

Relations with Ukraine after mid-1993 became temporarily frozen. It was the result of tensions between Warsaw and Kiev and complicated political situations in both countries. The fact that Poland sought the support of Russia for its accession to NATO led to temporarily mistrust by Ukraine in relation to the Polish government, and even the suspicion of Polish collaboration with Moscow. ${ }^{52}$ Relations between Kiev and Warsaw were also impacted by Moscow which was keen to keep Ukraine in its sphere of influence. The troublesome situation changed in the middle of 1994.

\subsection{Since 1994}

In 1994 Poland and Ukraine decided to rebuild each other's trust. In March 1994 during an official visit in Poland of the Foreign Minister of Ukraine, Anatoly Zlenko, both sides signed an agreement on the Protection of Memorials and Graves of the Victims of War and Political Repression and a Declaration of Principles for Shaping the Polish-Ukrainian partnership which emphasized the intention and will of both sides to enlarge cooperation in various areas. ${ }^{53}$ One year later both sides signed an agreement on safeguarding the rights of national minorities, which was the extension of treaty provisions in this regard.

\footnotetext{
${ }^{52}$ During that time Ukraine carried the negotiations with Russia on increasing transit fees for Russian gas to the west. At the same time during the visit of Boris Yeltsin in Warsaw in autumn of 1993, president of Poland Lech Wałęsa supported the establishment of a gas pipeline across the territory of Belarus and Poland. It weakened the position of Ukraine in negotiations as the Ukrainian gas pipeline was so far the only one which transported the gas to the West. The Polish gesture was considered by Ukraine as anti- Ukrainian. For more extended discussion on Polish- Ukrainian relations during this period see, Krzysztof Fedorowicz, Ukraina w polskiej polityce wschodniej w latach 1989- 1999 ( Poznań, Wydawnictwo Naukowe UAM), 2004. ${ }_{53}$ Margarita M. Balmaceda, On the Edge, Ukrainian-Central European-Russian Security Triangle (Budapest: Central European University Press, 2000),43.
} 
On March 21,1994 the Agreement on the Protection of the Memorials and Graves of Victims of War and Repression became the legal basis for cooperation between the two countries with regard to all national memorials. There were two institutions responsible for the realization of this agreement. On the Polish side it was The Council for the Protection of Resistance and Martyrdom Sites (Rada Ochrony Pamięci Walk i Męczeństwa). On the Ukrainian side it was The Inter-State Committee for Commemorating the Victims of Wars and Political Repressions. ${ }^{54}$

At the request of provincial committees, The Council for the Protection of Resistance and Martyrdom Sites gives an opinion about requests for commemorations. In general this institution has a monopoly on all possible sites of commemoration in Poland. The committee works through its provincial committees. Many decisions are made on the provincial level. However, those of special importance are made by the Council itself.

The Foreign Minister of Poland of that time, Wladyslaw Bartoszeski, stressed the special role of Ukraine and how this role determined the content of bilateral relations. Poland supported Ukraine on membership in the Council of Europe, while Ukraine supported Poland when trying to become a non-permanent member of the UN Security Council for the years 1996-1997. When in October 1995 U.S. Senator Kay Hutchison mentioned the existence of the alleged Polish-Ukrainian border disputes, both Polish and Ukrainian ambassadors denied this, stressing the good state of their mutual relationship. In the same year the Consultative Committee of Polish and Ukrainian Presidents was revived. All of this committee's actions were designed for the pursuit of integration with the European Union. In June of 1996, when the Ukrainian President Leonid Kuczma visited Poland, both sides signed a visa waiver agreement. During this visit both presidents signed an agreement of cooperation in the field of protection and return of cultural property lost or displaced during the war. In this document both countries undertook responsibility to conduct joint work of research and inventory in order to calculate the value, the number and the quality of movable cultural properties which are related to the history and culture of the other side. What is more, the Polish- Ukrainians Intergovernmental Commission was established. Its task was the identification and recording of all cultural goods on both sides. Meetings of the committee were held twice a year by turns

\footnotetext{
${ }^{54}$ Lech M. Nijakowski, Domeny symboliczne, Konflikty narodowe I etniczne w wymiarze symbolicznym (Warsaw: Wydawnictwo Naukowe Scholar, 2006), 295-296.
} 
in both countries. ${ }^{55}$ In subsequent years cooperation between two countries was developed and strengthened. Due to better cooperation between the two presidents, Aleksander Kwaśniewski took the initiative to improve relations even more. During his visit to Kiev in May 1997 both sides signed a join statement on agreement and reconciliation of which the main themes were the massacre of Poles in Volhynia and Action Vistula.

Another determining factor which influenced the legal measures for minorities in Poland was the reorientation of the country toward the West. The main goal of Poland as well as other Central and Eastern European countries after 1989 was to become a member of the European Union which was associated with particular membership criteria. Respect for and protection of minority rights was one of the pivotal requirements in order to proceed to accession and become a EU member state. In this way, Poland's democratization initiated political discussion over the rights and protection of minority groups in Poland. In the context of EU enlargement the peaceful development of Polish-Ukrainian relations was in the mutual interest of both countries. It was necessary to guarantee a legal framework for the minority population. In 1995 Poland signed the Convention for the Protection of National Minorities. It was ratified in 2000. In 1997 the Polish government established an Interdepartmental Group for National Minority Issues which was followed by founding of the Division of National Minorities by the Ministry of Interior and Administration. ${ }^{56}$ It was established in the context of EU accession and the discussion over various drafts of the Minorities Law.

During five years of work on the Minorities Law certain political parties raised their voice of criticism against adoption of this law. Approval of this law was mainly disputed by the parties of the center- right coalition government which consisted of League of Polish Families ( Liga Polskich Rodzin), Law and Justice (Prawoi Sprawiedliwość) and Self-defense (Samoobrona). In 2002 a draft law on minority rights was rejected by this rightist government. The biggest problems and fears were caused by the planned introduction of particular measures for use of minority languages in municipal institutions. The first project acknowledged the official use of a minority language if the local population contained an $8 \%$

\footnotetext{
${ }^{55}$ Ministry of Foreign Affairs," An agreement of cooperation in the field of protection and return of cultural property lost or displaced during the war, " Ministry of Foreign Affairs, http://www.traktaty.msz.gov.pl/fd.aspx?f=P0000007979.pdf (accessed on October 10, 2011).

${ }^{56}$ Peter Vermeersch, "A Minority at the Border: EU Enlargement and the Ukrainian Minority in Poland," East European Politics \& Societies 21, no. 3 (2007): 475-502. Academic Search Complete, EBSCOhost (accessed September 26, 2011),p.492.
} 
minority. This level was changed in subsequent draft upward to $20 \%$ and even $50 \%$. The Law on National and Ethnic Minorities and Regional Language was adopted in 2005 and set up the level at 20\%. ${ }^{57}$ It was surprising that in a mono-ethnic country such as Poland the Minorities Law raised so many fears. Minority communities were so small that none of those levels was likely to be reached, especially for Ukrainians who are scattered on various Polish territories. It resulted in raising an issue of Action Vistula. Activists of the Ukrainian minority argued that their inability to use the particular measures with regard to the use of language is the result of past circumstances. According to their claims if Action Vistula had not happened the total population of Ukrainians would be bigger than $20 \%$ in many municipalities.

\subsection{Orange Revolution}

The year 2004 was a special period for the Ukrainian- Polish relations. In the interstate relations of Poland and Ukraine, intensive friendship was pursued in the context of EU enlargement. It was particularly articulated during the Orange Revolution which took place in Ukraine between November 2004 and January 2005. The Orange Revolution occurred as a result of two months of protests in response to presidential election fraud in Ukraine which took place in November 2004. Immediately after the polls were closed, state television announced the victory of pro- Russian presidential candidate Viktor Yanukovych. However it turned out that the official electoral results differed significantly from the real results by about 11\%. The leaders of the opposition, Yulia Tymoshenko and Viktor Yushchenko, called upon Ukrainians to take up civil disobedience. The name of the revolution was taken from the color of orange as it was the symbol of Yanukovych's electoral staff.

Politicians in Poland promoted the idea of solidarity between citizens of both countries. The issues of conflicting memories were placed on the back burner. President Aleksander Kwaśniewski played a special role during this revolution. He supported the idea of a free and democratic Ukraine and called for agreement between Ukrainian politicians. What is more, he initiated the round table talks in Ukraine which gathered the leaders of Orange Revolution and representatives of the government but as well several European

\footnotetext{
${ }^{57}$ Law No. 141, "Ustawa o mniejszościach narodowych i etnicznych oraz o języku regionalnym”, Dziennik Ustaw (2005), No. 17.
} 
leaders such as EU foreign policy chief, Javier Solana, the president of Lithuania, Valdas Adamkus, and many others. Not only were Polish political leaders determined to support Ukraine, but most of Polish society sympathized with Ukrainians. People volunteered to help with protests on the street and on monitoring the elections. This period definitely contributed to a small change with regard to the negative image of Ukrainians in Poland. According to a survey conducted in 2003 by Public Opinion Research Center, one year before Orange Revolution, 19\% of Poles declared that they liked Ukrainians, one year later in 2004 this number increased to $29 \%$ of all Poles. ${ }^{58}$

Piotr Tyma, one of the Ukrainian minority activists at the time, now the president of Association of Ukrainians in Poland (Zwiazek Ukrainców w Polsce, ZUwP), said that the Orange Revolution had a positive impact on the Ukrainian minority in Poland. According to Tyma, it resulted in a more detailed program to support this minority in Poland. ${ }^{59}$ Friendly relations between the two countries did not stop with the Orange Revolution but continued to shape the debate over conflicting memories, especially with regard to commemoration and memorials which will be discussed in the next chapter.

This chapter has argued that the Polish-Ukrainian relations have developed particular opportunities for the Ukrainian minority in Poland to raise their memory claims. PolishUkrainian relations have been characterized by variable dynamics. International law gave a foundation to the Ukrainian minority for the protection of their identity and memory. Shifting institutional contexts offered conditions for the development of the minority's memories. The position of the Ukrainian minority in Poland after 1989 has changed dramatically. This minority was no longer dependent only on itself, was not controlled by authorities but has been receiving financial support to preserve their culture and customs. This did not remove the source of conflict and disputes, however it did give a basis for discussion of these problems. EU and NATO accession definitely had an impact on the development of friendly relations between Poland and Ukraine as EU and NATO accession requirements were dominant regulators of contacts between two countries. Desire for accession strengthened the willingness of Polish authorities to deal with Ukraine within legal and institutional

\footnotetext{
${ }^{58}$ Public Opinion Research Center, "Stosunek Polaków do innych narodów," Public Opinion Research Center, http://www.cbos.pl/SPISKOM.POL/2011/K_013_11.PDF (accessed October 11, 2011).

59 Peter Vermeersch, „National Minorities and International Change: Being Ukrainian in Contemporary Poland,” Europe-Asia Studies, 66, no.3 (2009): 449.
} 
frameworks in respect to the Ukrainian minority in Poland. It resulted as well in claims and demands of Ukrainian minority activists, which multiplied along with improvement of relations between Poland and Ukraine. The discourse over memory became more friendly, especially in the context of EU membership which will be seen especially in the commemorative practices discussed in next chapter. This chapter will illustrate that the position proposed by Polish authorities since 1989 has been strongly linked to the demands and claims of the Ukrainian minority. The institutional context developed through interstate relations allowed the Ukrainian minority to frame their memory demands. The next chapter will discuss the various responses of authorities to these demands on the domestic level. 


\title{
Chapter 3 Politics of memory toward the Ukrainian Minority
}

\author{
"History without tragedy does not exist \\ and knowledge is better and more wholesome \\ than ignorance 60 ,
}

\section{H.G. Adler}

There are undoubtedly reasons to remember the past. The question is if it is possible to shape memory in a way that can bring about peaceful co-existence between and among different groups and societies. What is more, the way memory is constructed says much about us as people. It says who we are. This chapter explores the process by which Ukrainian minority claims with regard to memory are transformed into public discourse. It provides insight into the core of what it is the politics of memory in Poland. The goal of this chapter is to illuminate the practice of memory politics and its definition on the domestic level. The politics of memory can be conducted on many levels. It takes on real form in the various initiatives taken by the authorities. Subjects of a conscious policy of memory pursued by the state's authorities are areas such as public holidays, rituals, organization of anniversaries, commemorations, erecting monuments, memorials, building museums, giving awards, naming the streets or schools, funding for books, publications, school programs and approval of textbooks. This chapter will focus on issues which are related to the claims the Ukrainian minority have made in contemporary Poland. They are concerned with such matters as compensation for past injustices, restitution of mainly cultural properties which belonged to Ukrainians before Action Vistula; commemorations of Action Vistula and Volhynia massacre and apologies made for them by the authorities; memorials and financial support. Each section will analyze several examples of such means of memorialization in order to analyze what kind of dialogue has occurred between the state' $s$ authorities and the Ukrainian minority with regard to conflicting memory issues and how each side is defining their memory in this dialogue. Do the state's authorities interfere with the minority's memory? If so are they justified? How far are authorities willing to recognize the minority's claims in regard to their memory of Action Vistula?

\footnotetext{
${ }^{60}$ Quoted in Raul Hilberg, The Politics of Memory (Chicago: Ivan R. Dee, 1996).
} 
According to the National Census from 2002 there were 27, 172 citizens who declared Ukrainian affiliation in Poland. The biggest concentration,11,881 persons, of this Ukrainian minority resides in northeast Poland (Warmia-Mazury), in western Poland it is 3,703, in the Podkarpackie region - 2,984, Pomorskie region- 2,831, Dolnoślaskie- 1,422, Podlaskie- 1,366, Lubuskie- 615, Mazowieckie- 579, Małopolskie- 472, Lubelskie-389 and Ślaskie-309. ${ }^{61}$ According to the 2002 census, in 9 northern municipalities of WarmińskoMazurskie province, Zachodnio-Pomorskie province and the Podkarpackie region the Ukrainian minority constitutes almost 10 percent of the population. Surveys show that this part of Poland is inhabited by the greatest number of people who think that agreement between Poland and Ukraine in terms of memory is impossible. ${ }^{62}$ This confirms the role of politics of memory in shaping the attitude toward minorities.

Despite the friendly relations between Poland and Ukraine, according to the minority representatives there is a constant tension in Poland between Ukrainians and Poles due to opposite understandings of historical events, especially those related to the ethnic cleansing and forced resettlement actions during and after World War Two. Ethnic Ukrainians express their feeling of being discriminated against and being perceived as the "eternal enemy of the Poles". ${ }^{63}$ Surveys show that in regions inhabited by large communities of Ukrainians there is the strongest sense of distance toward the Ukrainian minority. ${ }^{64}$ Members of the Ukrainian minority in Poland admit that they are not affected by direct discrimination but they feel a sense of inequality between the majority and the Ukrainian minority in Poland. ${ }^{65}$

The majority of Polish society declares itself to be tolerant; however, most Poles have difficulties with recognizing minority groups living in Poland. The knowledge of Poles about national and ethnic minorities is poor. What is more, surveys of Public Opinion Research Center (Centrum Badania Opinii Społecznej, CBOS) reveal that the majority of respondents

\footnotetext{
${ }^{61}$ Charakterystyka mniejszości narodowych i etnicznych w Polsce in Ministerstwo Spraw Wewnętrznych i Adminsitarcji, http://www2.mswia.gov.pl/portal.php?serwis=pl\&dzial=61\&id=37\#ukraincy (Accessem August 5, 2011).

62 Joanna Konieczna, „Polacy- UkraińceyPolska- Ukraina. Paradosky stosunków sąsiedzkich,” Fundacja Batorego, http://www.batory.org.pl/doc/paradoksy.pdf (accessed September 20, 2011), 20-22.

${ }^{63}$ Peter Vermeersch, "National Minorities and International Change: Being Ukrainian in Contemporary Poland," Europe-Asia Studies 61, no. 3, 2009, 435-456.

${ }^{64}$ Fundacja im. StefanaBatorego.

${ }^{65}$ The statement of Miron Kertyczak, president of Association of Ukrainian in Poland in. Sławomir Łodziński, "Problemy dyskryminacja osób należących do mniejszości narodowych I etnicznych w Polsce," Kancelaria Sejmu Biuro Studiów i Ekspertyz, grudzień, 2003, Nr 219: p.25.
} 
do not know anybody who declares a different identity other than Polish. As it is clear from the survey, almost $70 \%$ of respondents said they do not know a person from another nationality other than Polish, 27\% declared that they know someone who belongs to minority groups, only $1-2 \%$ admitted they belong to such a group. ${ }^{66}$ This means that the general attitude of vast majority of Polish society is and will be based on politics of memory developed by the state.

\subsection{Definitions of politics of memory}

Politics is always related to power. It cannot be that we limit our memory only to mainstream issues. It is necessary to protect different memories because they are all important elements to a shared European memory which determines European identity. Apart from individual memories which influence personal lives, there are a variety of forms used to transmit and constitute the memory of past events into the life of communities. The political constructions of memory are different than models created by individuals. Political memory seems to stand independently. In contrast to individual memories which are differential, political memory is based on a consistent narrative which tends to convey a particular message. What is more, political memory is expressed through modes of memory. It is not something which exists in the air but rather something which is created and manifested by visual sites, monuments, art, commemorations, education and History teaching by which it is possible to activate and strengthen fragmented memories of the past based on particular moments, but more importantly, allows the transmission of memory to new generations. In this sense the concept of the politics of memory is strongly linked to memory discrimination. The concept of discrimination is well known in the social sciences. Counteraction against discrimination has become a key objective of the European Union. An important type of discrimination is historical or memory's discrimination with regard to minorities. Minority groups often face intentional, but also unwittingly made restrictions in promoting alternative interpretations of history.

\footnotetext{
${ }^{66}$ Public Opinion Research Center, "Tożsamość narodowa Polaków oraz postrzeganie mniejszości narodowych i etnicznych w Polsce," Public Opinion Research Center, http://www.bezuprzedzen.org/doc/01Tozsamosc narodowa_Polakow_oraz_postrzeganie_mniejszosci_narodo wych i etnicznych w Polsce 2005 CBOS.pdf (accessed July 11, 2011).
} 
In Community law of the European Union, discrimination is defined in the European Union Council Directive No. 2000/43 of 29 June 2000. In Article 2 paragraph 2 it defines direct and indirect discrimination. Direct discrimination occurs when "due to racial or ethnic origin a person is treated less favorably than another person in a similar situation." On the other hand, indirect discrimination occurs when "an apparently neutral provision, criterion or practice can lead to particular disadvantage situation for persons of a particular racial or ethnic origin in relation to other persons unless that provision, criterion or practice is objectively justified by legitimated aim and means of achieving that aim are appropriate and necessary." As Poland is member of the EU, its laws are also part of Polish legal order. Thus, the practice adopted by the state authority against minorities, including those concerning the interpretation of the past, should depend on these EU legal definitions.

\subsection{Days of Commemoration}

Central for this section are commemorations of Action Vistula and the Volhynia massacre as they both portray the mutual reconciliation with regard to conflicting memory. It attempts to answer the question of its meanings both to the Ukrainian minority as well as to the authorities. By recognizing days of commemoration authorities validate the memory of minorities. It provides a significant function of legitimization of memory interpretations. Since 1989 there were four significant anniversaries observed: in 1993 and again in 2003the $50^{\text {th }}$ and $60^{\text {th }}$ anniversary of massacre of Poles in Volhynia, and in 1997 and 2002 of Action Vistula. The commemoration in 1993 was more modest than the one in 2003. With Action Vistula it was the opposite, the anniversary in 2002 was much more modest than the one commemorated in 1997.

\subsubsection{Commemoration of Action Vistula}

Even though Poles and Ukrainians were able to achieve enormous progress in assessing the conflicted past, commemoration of Action Vistula every year brings about claims of Ukrainians calling for condemning the past events by Poles. The largest commemorative events take place every year in Jaworzno, as well as in Przemyśl. They gather families of victims, representatives of local authorities and many other representatives of the Ukrainian minority. Local authorities every year condemn the Action Vistula and 
underline that such acts against civilians should never take place. In the context of the 50th anniversary commemoration of Action Vistula, President of Ukraine Viktor Yushchenko said in Lvov that the Action Vistula was an crime committed by the communist regime. He appealed to the Ukrainians and to Poles not to burden mutual relations with recriminations about the past. During the commemorative evening of Action Vistula in the Lviv Opera House he reminded the audience that the perpetrator of this operation was the totalitarian communist regime. He called for condemnation of this regime by Ukraine, Poland and all the world. Nevertheless, demands for apology are made by the Ukrainian minority every year. On January 2007 the World Congress of Ukrainians asked the Council of Europe, the United Nations, the Organization for Security and Cooperation in Europe and the European Union for support in submitting a claim against Poland with regard to apologies and reparations for Action Vistula. The World Congress of Ukrainians described Action Vistula as the greatest tragedy of the Ukrainian nation. The then President of Poland, Lech Kaczyński, as well as the Foreign Ministry, did not comment on these demands.

\subsubsection{Commemorations of the Volhynia Massacre}

In Polish- Ukrainian dialogue the $60^{\text {th }}$ commemoration of Volhynia massacre was one of the achievements in the politics of reconciliation. Central to the attention of politicians was the issue of preparing observance of the sixtieth anniversary of the tragic events in Volhynia. Before the event in 2003, Aleksander Kwaśniewski promised to the veteran communities that the anniversary would be organized at the highest level. And even though it was a really difficult topic and, the closer to the ceremony the more obstacles appeared due to opposed interpretations of history, he managed to do so. Commemoration of Volhynia massacre took place without any incidents. There were only small problems with regard to the inscription on monuments, however the problem had been addressed one day before.

On 11 July, key Polish and Ukrainian political figures met to commemorate the $60^{\text {th }}$ anniversary of tragic events in Volhynia of 1943. In the ceremony Polish President Aleksander Kwaśniewski participated with a group of deputies, senators and representatives of the Ukrainian minority in Poland and Ukraine's President Leonid Kuchma. ${ }^{67}$

\footnotetext{
${ }^{67}$ Maw, „Siwiec o przygotowaniach do 60. Rocznicy zbrodni wołyńskiej,” Gazeta Wyborcza, June 26, 2003.
} 
On July, 1943 in Pawliwce 300 people were brutally murdered. Among them were men, women, children, old men. During the night of 11 to 12 July the Ukrainian Insurgent Army troops attacked 167 villages at the same time, resulting in death about 10 thousand Poles. According to the latest estimates of Polish historians, during the massacre in Volhynia alone there were killed between 35 and 60 thousand people. According to Polish historians, the Ukrainian Insurgent Army killed from 50 to 60 thousand Poles, while Ukrainian historians give a number of 40 to 50 thousand. Also on the Ukrainian side were the victims in the civilian population of about 20,000. Most of the victims were unarmed civilians. Many documents show, however, that Poles were brutally killed using axes and saws. ${ }^{68}$

Responsibility for this tragedy should not be a burden of the Ukrainian nation as a whole, but specific political forces that were decision-makers in these atrocities. During one of the ceremonies commemorating the 60th anniversary of the tragic events, Aleksander Kwaśniewski delivered a speech in which he underlined that:

"We cannot blame Ukrainian people for the massacre committed on the Polish population. There are no nations - that are the culprits. Real people bear the responsibility for the crimes" ${ }^{\prime 6}$.

The ceremony began with a Mass celebrated in the Catholic cemetery of the victims of Volhynia. It was led by the Lviv Greek Catholic and a Roman Catholic cardinal. Then, an ecumenical prayer took place with representatives of various religions. During the ceremony, as a witness of the tragic events and a person who managed to survive the inhuman treatment from the units of the UPA, a former resident of Pawliwce Stanislaw Filipowicz presented a description of the events that took place exactly 60 years before, on 11 July. At the end of his speech he said:

\footnotetext{
${ }^{68}$ Jagienka Wilczak, „Wołyńskie Jedwabne,” Polityka, 12 July, 2003, 24-27.

${ }^{69}$ Informacyjna Agencja Radiowa, „W Pawliwce zakończyły się uroczystości upamiętniające 60-lecie tragicznych wydarzeń na Wołyniu," Informacyjna Agencja Radiowa, http://www.bankier.pl/wiadomosc/W-Pawliwcezakonczyly-sie-uroczystosci-upamietniajace-60-lecie-tragicznych-wydarzen-na-Wolyniu-802388.html (accessed September 1, 2011).
} 
"Today we are here to give witness to the truth, because truth can only ease the pain of losing loved ones. Only the truth will build the foundation for a better, common future of Poles and Ukrainians. ${ }^{70 "}$

After the speeches Polish and Ukrainian presidents laid wreaths to the graves of Poles who were tragically killed and lit candles. Presidents Aleksander Kwaśniewski and Leonid Kuczma unveiled a monument of Polish-Ukrainian reconciliation "Memory - Grief - Unity" . They read and signed a joint statement "On Reconciliation - during the 60th anniversary of the tragic events in Volhynia." The statement expresses words of sympathy for families of victims. The crimes committed in the past against both nations were condemned. As a foundation to build good neighborly relations, an appeal of John Paul II to the Poles and Ukrainians was read:

"It is time to break away from the painful past! (...) Let forgiveness - given and received - spread like a healing balm in every heart. Let all, through purification of historical memory, value more all what unites rather than what divides, so that together we can build a future based on mutual respect, cooperation and true brotherly solidarity. ${ }^{71 "}$

Leonid Kuczma condemned the violence and he urged people to search for historical truth. He condemned violence against innocent people. There were no concrete accusations made against specific individuals, however Kuczma said that responsibility for the repression against the innocent civilians rests with the extremist activists who were in the ranks of the national liberation movements of the two nations. The Polish President expressed his open protest against the moral ideology behind Volhynian massacre, initiated by certain members Organization of Ukrainian Nationalists and Ukrainian Insurgent Army but at the same time he highlighted the positive merits of the liberation movement, which fought for the independence of the Ukrainian state. He stressed that the responsibility of these tragic acts rests on its initiators and perpetrators from the OUN-UPA belonging to a specific branch.

\footnotetext{
${ }^{70}$ Wilczak, 24-27.

${ }^{71}$ Marcin Wojciechowski, „Prezydenci Polski i Ukrainy jednali się w rocznicę tragedii na Wołyniu," Gazeta Wyborcza, July 11, 2003.
} 
What was significant in this ceremony was that both presidents underscored the meaning of awareness and knowledge about the events of Volhynia which was very low in both countries. They emphasized the role of historians and political scientists on both sides in researching the events in Volhynia and other acts of violence between Poles and Ukrainians during World War II. Poland should not in any way allow such research to become a competitive form of mutual accusations because the value of human life is not subject to a quantitative criterion. Only such a complementary approach to the problem based on honesty will give an objective result. Aleksander Kwasniewski referred to the sad events surrounding the death of the Ukrainian people, who perished at the hands of the Poles during Action Vistula. As repeatedly stressed, it's not just about responsibility, but to raise awareness that no one is without fault. In this sense the task of politicians is not to alleviate the historical differences but to explain them within an environment of mutual respect.

\subsection{Monuments}

The real conflict between Poland and Ukraine starts at the symbolic level. It is not a matter of historical interpretations but about justifying the right of different groups to have power over the space. Politics has a special role in these symbolic conflicts as they make the parties of the conflict more friendly or more hostile. We cannot forget about symbolic disputes in politics toward minorities. Conflicts over memorials are an important issue in political campaigns. Ethnic groups are focused on meeting symbolic needs rather than social needs.

Aleksander Wallis says that the monuments are erected because of belief that the particular history they represent is important. He underlines that they have enormous social functions. ${ }^{72}$ They not only solidify social values but are a part of ideological struggle. So the material memorialization of the past is one of the means to project memory. Memorials, cemeteries or plaques are the great sources of memory's shape. Their form or even the way people care about them says a lot about the quality of particular memory and its meaning for the individual, group or state authorities. The goal of this part of my work is to analyze a few examples of memorials as elements which influence the integration of the Ukrainian minority and to illustrate the importance of memorials for the memory of minorities in Poland. This

\footnotetext{
72 Lech M. Nijakowska, "Socjologia Pomnika, Czyli w Poszukiwaniu Fatalnej Siły Kamienia," in Domeny Symboliczne, ed. Lech M. Nijakowski (Warsaw: Wydawnictwo Naukowe Scholar, 2006),66-69.
} 
part emphasizes that the memorial side of memory is a complex process in which different actors play important roles. If we think about monuments, memorials or any sort of commemoration, we hardly ever think about long decision- making processes prior to the establishment of final versions of commemoration. But in the end they have a crucial influence on the outcome.

An often recurring situation in regard to memorials in Poland is the encounter between the voice of Ukrainian minority to commemorate its citizens and the Polish voice of rejection to commemorate any member of the Ukrainian Insurgent Army. The main issue is the selection of the victims. The cases where the commemoration concerns civilians do not raise too many controversies. However, commemoration of a group in civilians of which a few were UPA members raise various controversies on both sides.

\subsubsection{Jaworzno and Kharkov}

The memorial conflict which was positively resolved was the memorial to victims of the Central Labour Camp in Jaworzno. It was one of the biggest sites of conflict between the two countries. During the war the camp was run by Nazi Germany. Later it supposedly served as a prison camp for Ukrainians suspected of collaboration with UPA. However most prisoners of that time were Ukrainians arrested during the Vistula operation. Of almost 4000 people, 700 were women and children. The demands for restitution for former prisoners of the Central Labor Camp and their families was of special importance after 1989. In 2004 the Council of Ministers decided to compensate former prisoners with cash benefits as a result of legislation submitted by representatives of the Ukrainian minority. On 23 May 1998 the President of Poland, Aleksander Kwaśniewski, and president of Ukraine, Leonid Kuczma, unveiled the memorial for victims of the camp.

Another gesture which attempted to deal with the troubled past was a meeting of Leonid Kuczma and Aleksander Kwaśniewski in Kharkov. In June 1998, both presidents took part in the ceremony of laying the cornerstone for the construction of a Ukrainian-Polish cemetery for the victims of totalitarianism. 
Jaworzno and Kharkov were opportunities to overcome the stereotypical mutual treatment with regard to conflicting interpretations of the past and also presented a chance for the implementation of a strategic partnership built through overcoming the painful legacy of history. Nevertheless, after 1989 there was significant increase of memorials, especially those with regard to UPA members. Such commemorations brought up many controversies. On the one hand there were many stories with happy endings such as the erection of the memorial for the prisoners of Central Labour Camp in Jaworzno (Centralny Obóz Pracy w Jaworznie), the memorial in Zawadka Morochowska, or the one for Ukrainian soldiers who died in a camp in Dąbie. The most controversial memorials for UPA members took place in Hruszowice. The leaders of Ukrainian minority claim that the discussion over "illegal UPA memorials" began to be described as acts against Poland only when it actually acquired political meaning. They underlined that earlier the commemorations for UPA members did not face any negative reactions from any locals. When the authorities placed greater importance on the memorial and victim selection process, local people started to see memorials in a negative light. According to the Ukrainian minority, the conflict over memorials is the result of politization of local memorials and fear of local authorities to make decisions.

\subsubsection{Bircza and Liszna}

Another conflict which presents the different interpretations of the past took place in 2000. It started with problems over the burial of a few UPA members killed during the attack on Bircza and Ukrainian civilians in Liszna sentenced to death by the court in Krakow in 1947. In the beginning, the conflict was shaped by negotiations over the burials. However, when they were finished, the conflict turned into the negotiations over two plaques commemorating the Ukrainians killed in Bircza and Liszna. On 3 August 2000 the Ukrainian side formally accepted the text which was supposed to be on the plaque. The two texts said: " For the Ukrainian Insurgents executed for Ukrainian freedom on 7 January 1946 in Bircza" (Powstańcom ukraińskim polegtym za wolność Ukrainy 7 stycznia $1946 r$ r.w Birczy) and the other :" For the Ukrainian Insurgents executed for Ukrainian freedom on 22 May 1947 in Liszna" (Powstańcom ukraińskim straconym za wolność Ukrainy 22 maja 1947 w Lisznej). Andrzej Przewoźnik, the head of Council for the Protection of Resistance and Martyrdom Sites, stopped the process of implementing the plaques. All of them were removed and replaced. The final notes were: "Here lie the Ukrainian Insurgent Army soldiers executed on 22 May 1947 in Liszna as a result of the Polish Military Court's sentence" ( Tu spoczywaja 
żolnierze Ukraińskie Powstańczej Armii straceni 22 maja 1947 roku w Lisznej w wyniku wyroku polskiego Sadu Wojskowego w Sanoku). ${ }^{73}$

The conflict over the plaque's content shows that it was based upon the different categorization of UPA members. Poles call the UPA brutal fascists while Ukrainians consider UPA as an army that fought for independence of the country. The Ukrainian minority accused the Polish side that the negotiations over the plaques included only the president of Ukrainian Association in Poland and did not include the opinions of people really interested in the issue.

\subsubsection{Pawłokoma}

One of the answers to the memory conflict can be seen the case of the small village of Pawlokoma. It is an example of one of few villages where Polish armed formations killed many of Ukrainian civilians. On $3^{\text {rd }}$ March 1943 in Pawłokoma an armed formation "Wacław", together with inhabitants of neighboring villages, murdered almost 400 Ukrainians in revenge for the murder of 11 Poles living in the village. Such operations were undertaken in many other small villages such as Piskorowice (300-400 dead), Małkowice etc. For a long time the Catholic Church together with local communities did not allow commemoration of the murdered Ukrainians. Only the opening of Cemetery of Eaglets initiated the discussion over commemoration of Ukrainians. The Cemetery of Eaglets has been a problematic and conflicting subject for Warsaw, Moscow and Kiev. It is a burial place for Poles who died during the Polish-Ukrainian War between 1918 and 1920 which was a conflict over the territory of Eastern Galicia. After World War Two the Cemetery fell into disrepair. Soviet power destroyed tombstones, monuments and many sculptures of the cemetery. In 1971 it was completely destroyed by the Soviet tanks. Part of the cemetery was turned into an road. For many years Warsaw and Poles in Lviv were helpless. There was nothing that could be done at that time with regard to the cemetery. For Poles it is was a symbol of heroism and burial place for over two thousand soldiers, while for Ukrainians it was a symbol of Polish domination. Only after 1989 the reconstruction process of the cemetery began. The Cemetery of Eaglets became a part of negotiations over the memorials between Poles and Ukrainians. In 2005 president of Poland Aleksander Kwaśniewski and president of Ukraine Viktor Yushchenko

\footnotetext{
${ }^{73}$ Nijakowski. Domeny symboliczne. 299.
} 
attended the opening ceremony of the Cemetery of Eaglets which was considered a symbolic reconciliation between the two countries.

Consequently the discussions over the Pawłokoma's commemoration gained importance. The discussions between the local government of Dynów, the commune to which Pawłokoma belonged and representatives of Polish authorities took place in 2005 in Warsaw. During the meeting of the Council for the Protection of Resistance and Martyrdom Sites, it was agreed to support financially the project of the Ukrainian memorial and to verify the list of victims with the support of the Institute of National Remembrance. ${ }^{74}$ The long discussions ended up in a compromise. The Polish side agreed to the Ukrainian memorial, requiring at the same time a memorial of Poles murdered by the Ukrainian Insurgent Army shortly before the brutal operation of Poles in Pawlokoma village. On 13 May 2006, the President of Poland Lech Kaczyński together with the President of Ukraine Віктор Андрійович Ющенко unveiled two memorials in the small village of Pawłokoma. During the ceremony Kaczyński did not apologize for the crime; however his speech gave a fully accurate historical description. After the ceremony he acknowledged that the statements of both parties were sufficient.

One of the residents of Pawłokoma, Tatiana Czuma attended the ceremony. On the day of the tragedy she was seven years old; she witnessed the tragic events that took place then in the village. She was not satisfied with the ceremony. She expressed objections to the content of the inscription on the monument in Polish and Ukrainian, particularly to the word "killed" as she said people were murdered, not killed. The President of the Association of Ukrainians in Przemyśl commented that there was no doubt: - "How long we waited for the ceremony, preparations were so difficult that it was an important day for us. And most important for people who are in this cemetery have their loved ones."

Pawłokoma is one of the symbols of the tragedy of the Polish and Ukraine conflict. To Pawłokoma arrived members of the Brotherhood of the Veterans (Bractwa Weteranów) of the Ukrainian Insurgent Army. They emphasized that it is high time to end the mutual hatred. Polish and Ukrainian presidents spoke of reconciliation. Both presidents stressed that on both sides of the border there is still a lot of nameless graves, and their role as heads of state is to ensure that families of these victims are able to put up crosses and pray over the

\footnotetext{
${ }^{74}$ Andrzej Szpiciński, Pamięć zbiorowa jako czynnik integracji i źródło konfliktów (Warsaw: Wydawnictwo Naukowe Scholar, 2009), 60.
} 
graves. The presidents made the announcement that this commemoration would be followed by extensive cooperation and exchanges of young people and local governments to learn and discover a common history.

The leaders of both countries put bouquets of flowers and lit candles under the cross commemorating the Polish dead. The appeals for reconciliation and forgiveness in Pawłokoma were expressed by the Roman Catholic Church leaders and Greek Catholic Ukrainian Archbishop Jozef Michalik and Lubomir Husar. "We apologize and ask for forgiveness," they said.

For the Ukrainians the Pawłokoma tragedy became a symbol of their nation, as for the Poles Volhynia, Huta Pieniacka and many other places in Ukraine. The memorial plaque in Pawłokoma inscribed the names of 366 victims. Many Polish historians believe that the number of murdered people was smaller.

The institutional process of commemoration includes many actors and elements such as local governments and associations. The material commemorations give groups symbolic power over the site. The State authorities' role is to organize the commemorations, and to maintain the cemeteries and other places of memory. In this sense the authorities have a huge monopoly on symbols which have enormous meaning for memory conflicts. The symbols with inscriptions often cause the conflicts. These examples cited here show that commemorations and memorials are related to the power of authorities. The major responsibility lies on the authorities and their initiative. Even their speeches are not without meaning. They are often the ones who initiate the particular actions, they make decisions as well as mediate between two sides. This is why consistency is so important in this. Lack of it can strengthen conflict and it may change the character of the place of commemoration. Instead of creating space for peaceful co-existence it may create a space of negative contest between two interpretations of memory. 


\subsection{Reparation}

A claim for reparations has its own function on the individual level as well as on the collective level. On both it provides moral restitution for the victims and their families. ${ }^{75}$ Central to Ukrainian demands was regulation of reparations and support with regard to commemoration of Action Vistula. Those issues required certain initiatives not only from Ukrainian minority activists, but also from policy-makers. These issues were raised at the parliamentary level while preparing the law on national and ethnic minorities and regional language by the president of the Association of Ukrainians in Poland, Miron Kertyczak. Such official discussions represented the needs of the Ukrainian minority and gave Poland a general overview of problems which were of special importance for the Ukrainian community. Nevertheless, at that time there were no visible actions to resolve problematic issues of the past. The friendly development of relations between Poland and Ukraine encouraged many descendants of Ukrainians expelled during post- war years in Action Vistula to fight for reparations. Numerous cases of such occurred particularly after the Orange Revolution.

After the change in the political system in Poland in 1989 many members of Ukrainian minority began to seek compensation for lost properties, houses and farms. Most of them were seized by the communist state, based on the decree of 27 July, 1949 which gave the state the right to take over all real estate which was not in the actual possession of property owners.

Due to Action Vistula entire villages were displaced on the basis of collective lists. There were no administrative decisions issued. According to the Director of the Civil Rights Team in the Office of Ombudsman, Dariusz Chaciński, the lack of administrative decisions undermines the validity of Action Vistula and gives a basis for claims by displaced Ukrainians and their families. On this basis several representatives of Ukrainian minority entered lawsuits against the state. Most of them ended up in failure due to similar reasons. According to the court, such claims were accurate only twelve months after the law on state's responsibility for damages caused by public officials was introduced. The problem is that this

\footnotetext{
${ }^{75}$ Christopher Kutz, „Justice in Reparations: The Cost of Memory and the Value of Talk," Philosophy \&Public Affairs, No.3(2004): 282.
} 
law was introduced in November, 1956. According to minority activists there is a gap in law with regard to reparations.

The described examples show that friendly relations of Poland and Ukraine do not often overlap with the domestic claims of minorities. Memorials, commemorations of Action Vistula as well as claims for reparations are elements of the broader process of negotiation between the state, Polish society, and the Ukrainian minority. The outside influences, such as accession to the EU or the Orange Revolution may speed some decisions, as in the case of Pawłokoma. In this case, the role of authorities positively resolved the conflict. On the other hand, there are always possible situations of dispute as when the voice of Ukrainians calling for commemorating their citizens meets with the Polish voice of locals or authorities who reject all forms of commemorations with regard to UPA and crimes against Poles.

The politics of memory should be based on several elements of which quality of education and quality of institutions are the most important. They both play an important role in popularizing history and they are pivotal for decisions such as erecting monuments, plaques or other commemorative symbols. By improving the quality of institutions there is a chance that certain decisions as well as actions will be undertaken at the appropriate time, not only when they are politically needed or useful. 


\section{CONCLUSIONS}

"The past does not interfere with the present directly: all interference is mediated by the story. What course that interference will ultimately take is decided on the battlefield of memory, where stories are the troops and the storytellers are the shrewd or hapless commanders of the fighting forces. The lessons to be drawn from the past are the prime stakes of the battle. ${ }^{76, "}$

\section{Zygmunt Bauman}

This thesis has presented the ways in which memories of Ukrainian minority have been recognized in post-communist Poland. Both countries have made huge progress in terms of negotiating a legal basis for minorities to express their identity. Nevertheless, reconciliation seems to be complicated, even if state authorities recognized the conflicting interpretations and attempted to reexamine the troublesome past.

We are what we remember. In that case the way how people define the past says more about the society than about the actual events. Memory and its interpretations are among the most important functions of society. The reason for this is that where we come from and what our past is are inherent to the construction of the national identity. Special responsibility for shaping civil society rests on the quality of the policy of memory, whether based on attitudes of tolerance and openness, or alternatively on intolerance and hostility toward others.

By developing and providing the institutions and tools which promote the pluralization of memories there is the chance of revaluing the individual memories of society and influencing the greater openness and tolerance among society. Institutional pluralism gives opportunities for dialogue between conflicting memories and perspectives. It confronts different interpretations and illustrates the importance of diversity. The politics of memory influence and shape people's responses to the present.

Sometimes attempting to come to the historical truth is pointless and will last forever. The reality of conflict looks different to competing sides. There will always be individual memories which demand recognition. Memory with negative emotions requires efforts for

\footnotetext{
${ }^{76}$ Zygmunt Bauman, '"Categorial Murder or: How to remember the Holocaust," in Emmy Barouh (ed), History and Memory. Bulgaria: Facing the Holocaust (Sofia: Open Society Foundation, 2003), 18.
} 
mutual and deeper understanding and forgiveness which is always the foundation of unity. The actions of politicians have acted as an incentive for both Poles and Ukrainians to look at difficult historical events from the perspective of forgiveness and reconciliation rather than from the perspective of accusations, judgments or endless disputes about the number of victims on one or the other side. In the whole complex history of Polish - Ukrainian relations politicians have played an important role in shaping memory. Their relationship had in the past and currently has a large impact on both Poles and Ukrainians. Despite the difficulties they face, it is important to give examples of dialogue and reconciliation between the two nations, which in the $20^{\text {th }}$ century have passed through a lot of bitterness and anguish. It is important that the actions initiated by politicians serve as a positive experience that will help view from a distance old disputes and mutual distrust. There is a strong need to overcome the cult of victims and to open the vaults of uncomfortable historical truth to both Poles and Ukrainians. What is therefore needed is even more intensive work, commitment, initiatives and steps of rapprochement towards each other's needs. As the result of decades of propaganda the two communities are burdened with negative stereotypes. Change in perceptions of each other's memory and mutual relations and cooperation, must embrace the widest circle of people and politicians. This requires the undertaking of new initiatives in a constant manner and at various levels. It is important to remember that reconciliation is a long process that begins with recognizing one side's own mistakes. Historical legacy should not be allowed to inhibit mutual cooperation at various levels. Examination and investigation of difficult events from the past should pass into the hands of competent historians, while the wider bodies should focus their attention on the future.

Reborn Poland after 1989 needs a new interpretation of the past. Especially when it is divided between different communities. The politics of memory is conducted by all countries. On one hand it should remind people of the experiences which bring pride and consequently strengthen people's identity. On the other hand it should be careful not to forget about smaller communities.

The state authorities should not reject national pride, but they should also create the space for differing views. The core issue is to create a sense of community by recognizing someone else's past as worthy to remember. At the bottom line, the politics of memory should not be based on the exclusion of a minority group , community or any other part of society 
especially if the goal is to build a democratic, western society within European and transatlantic frameworks.

The example of politics of memory with regard to the Ukrainian minority shows that the recent actions of authorities have been important for maintaining diversity and peaceful coexistence. It is important for the recognition of the multiplicity of different interpretations and respect for those who think differently.

This thesis has also argued that the memory politics with regard to the Ukrainian minority is often inconsistent and is characterized by the minimization of guilt. Political opportunities for the memory claims of Ukrainian minority depended on changes in international relations as well as on responses on the domestic level. It is difficult to define the proper politics of memory and what is historical discrimination when the normal scenario for each state has been the multiplicity of interpretations of history. The problem of memory politics is related to the particular privilege owned by authorities, elites or media who make decisions in relation to memory and historical interpretations. Full equality between interpretations is almost impossible. Memory discrimination through politics occurs when the alternative memory is treated less favorably than the dominative memory. It is visible through the politics of memory which categorize the historical heroes and institutions, assess the events of the past, and makes choices with regard to historiography and interpretations. Such politics is legitimated by public opinion and are, spread through official and unofficial institutions and instruments. As a result, the interpretation which is dominant, the one we receive, is because of a complicated and negotiated politics of memory. 


\section{Bibliography:}

\section{Books:}

Anderson, Benedict. Imagined Communities. London: Verso, 2006.

Berg, Eiki and EhinPiret, Identity and Foreign Policy, Baltic- Russian Relations and European Integration. Tartu: Ashgate, 2009.

Bernd, Rachel. Minority Rights in Central and Eastern Europe. New York: Routledge, 2009.

Brubaker, Rogers. Nationalism Reframed. Nationhood and the national question in the New Europe. Cambridge: Cambridge University Press, 1996.

Budryte, Dovile. Taming Nationalism?Political Community Bulding in the Post- Soviet Baltic States. Ashgate, 2005.

Burke, Peter. Varieties of Cultural History. New York: Cornell University Press, 1997.

Connerton, Paul. How societies remember. Madrit: Cambridge University Press, 1989.

Deak, Istvan, Jan T. Gross and Tony Judth. The Politics of Retribution in Europe. Princetown: Princeton University Press, 2000.

Eder, Klaus and SpohnWillfried. Collective Memory and European Identity. Hants: Ashgate, 2005.

Emden, Christian, and David Midgley.Cultural Memory and Historical Consciousness in the German-Speaking World Since 1500. Bern: Peter Lang, 2004.

Gillis, John R. Commemorations, The Politics of National Identity. Princeton: Princeton University Press, 1994.

Halbwachs, Maurice. On Collective Memory. Chicago: The University of Chicago Press, 1952. 
Hodgkin, Katharine and Susannah Radstone. Contested Past, The Politics of Memory. London and New York: Routledge, 2003.

Irwin-Zarecka, Iwona. Frames of Remembrance, The dynamics of collective memory. New Brunswick: Transaction Publishers, 2009.

Korzeniowski, Bartosz. „Demokratyzacja pamięci wobec problemu asymilacji pamięci mniejszości w Polsce po 1989.” in Etniczność, pamięć, asymilacja, wokót problemów zachowania tożsamości mniejszości narodowych i etnicznych w Polsce, edited by Lech M.Nijakowski, 129-141. Warsaw: Wydawnictwo Sejmowe,2009.

Langenbacher, Eric, and Yossi Shain. Power and the Past. Collective memory and international relations. Washington: Georgetown University Press, 2010.

Motyka, Grzegorz and Dariusz Libionka. Antypolska Akcja OUN-UPA 1943-1944, Fakty i Interpretacje. Warsaw: Instytut Pamięci Narodowej, 2002.

Ned Lebow, KansteinerWulf Richard and Fogy Claudio. The Politics of Memory in Postwar Europe. Durham and London: Duke University Press, 2006.

Nijakowski, Lech M. Polska polityka pamięci, esej socjologiczny. Warsaw: Wydawnictwa Akademickie i Porfesjonalne, 2008.

Phillips, Kendall R.. Framing Public Memory. Tuscaloosa:The University of Alabama Press, 2004.

Raikka, Juha. Do we need minority rights? Conceptual Issues. Hague: Kluwer Law International, 1996.

Ricoeur, Paul. Memory History Forgetting. Chicago and London: The University of Chicago Press, 2004.

Rosenberg, Tina. The Haiunted Land, Facing Europe's Ghosts After Communism. New York: Random House, 1995.

Snyder, Timothy. The Reconstruction of Nations, Poland, Ukraine, Lithuania, Belarus 15691999. New Haven \& London: Yale University Press, 2003. 
Szacka, Barbara. Czas przeszły, pamięć, mit. Warsaw: Wydawnictwo Naukowe Scholar, 2006.

Werner- Muller, Jan. Memory and Power in Post- War Europe. Cambridge: Cambridge University Press, 2002.

Wertsch V., James .Voices of Collective Remembering. Cambridge: Cambridge University press, 2002.

Zaborowski, Marcin. Germany, Poland and Europe: Conflict, Co- operation and Europeanisation. Manchester: Manchester University Press, 2004.

\section{Articles:}

Assmann, Jan. "Collective Memory and Cultural Identity." New German Critique, no. 65 (1995): 125-133.

Buhbe, Matthes and Iris Kempe. Russia the EU and the Baltic States, Enhancing the Potential for Cooperation. Moscow: Friedrich, Eert, Stiftung, 2005.

http://www.fesbaltic.ee/public/Tekstid/Russia_the_EU_and_Baltic_States.pdf

Connolly, Katie. "Poles Furious at German War Booty Claims.” The Guardian, August 29, 2007.

Cwiek-Karpowicz, Jarosław. "Public opinion on fears and hopes related to Russia and Germany." The Institute of Public Affairs (2005).

http://www.isp.org.pl/files/16004582900515529001143205142.pdf.

Erikson, Erik. "Reflections on the dissent of contemporary youth." International Journal of Psychoanalysis 51 (1970): 11-22.

Garton Ash, Timothy. “ Trials, Purges and History Lessons: Treating a Difficult Past in PostCommunist Europe." in Memory \& Power in Post- War Europe, Studies in Presence of the Past, ed. Jan-Werner Muller . Cambridge: Cambridge University Press, 2002.

Garton Ash, Timothy. “ The Freedom of Historical Debate is Under Attack by the Memory Policy. “ The Guardian, October 16, 2008. 
Łodziński, Sławomir. "Problemy dyskryminacja osób należących do mniejszości narodowych I etnicznych w Polsce.” Kancelaria Sejmu Biuro Studiów i Ekspertyz, grudzień, 2003, Nr 219.

Malksoo, Maria. "The Memory Politics of Becoming European: The East European Subalterns and The Collective Memory of Europe.” European Journal of International Relations15, no. 4 (2009), http://www.memoryatwar.org/pdf/Malksoo_EJIR_Dec_2009-1.pdf.

Padraick, Kenney. "Martyrs and Neighbors: Sources of Reconciliation in Central Europe." Common Knowledge 13, no. 1 (2007),

http://muse.jhu.edu/login?uri=/journals/common_knowledge/v013/13.1kenney.html.

Waskiewicz, Andrzej. "The Polish Home Army and the Politics of Memory." East European Politics \& Societies 24, no. 1 (2010), http://eep.sagepub.com/content/24/1/44.abstract.

Vermeersch, Peter. "A Minority at the Border: EU Enlargement and the Ukrainian Minority in Poland." East European Politics \& Societies 21, no. 3 (Summer2007 2007): 475-502. Academic Search Complete, EBSCOhost (accessed September 26, 2011).

Vermeersch, Peter. "National Minorities and International Change: Being Ukrainian in Contemporary Poland." Europe-Asia Studies 61, no. 3 (May 2009): 435-456. Academic Search Complete, EBSCOhost (accessed September 25, 2011).

Zehfuss, Maja. "Constructivism and Identity.” European Journal of International Relation 7, no. 3 (September 2001): 315-348.

\section{$\underline{\text { Websites: }}$}

Central Statistical Office. "Wyniki Narodowego Spisu Powszechnego Ludności i Mieszkań $2002 \mathrm{w}$ zakresie deklarowanej narodowości oraz języka używanego w domu" Central Statistical Office, http://www.stat.gov.pl/gus/8185_PLK_HTML.htm.

Centrum Badań Opinii Społecznej. ”Tożsamość narodowa Polaków oraz postrzeganie mniejszości narodowych i etnicznych w Polsce” CBOS, 
http://www.bezuprzedzen.org/doc/01Tozsamosc_narodowa_Polakow_oraz_postrzeganie_mni ejszosci_narodowych_i_etnicznych_w_Polsce_2005_CBOS.pdf (accessedJuly 11, 2011).

Główny Urząd Statystyczny. "Wyniki Narodowego Spisu Powszechnego Ludności i

Mieszkań 2002 w zakresie deklarowanej narodowości oraz języka używanego w domu” GUS, http://www.stat.gov.pl/gus/5840_4520_PLK_HTML.htm (accessedJuly 1, 2011).

Copenhagen European Council. "Presidency Conclusions" Copenhagen European Council, http://www.europarl.europa.eu/enlargement/ec/pdf/cop_en.pdf (accessed July1, 2011). 